\title{
$[1]$
}

\section{The Creation of a Gender Role: The Male Domestic Servant}

Domestic service was very much a fixture of colonial society in Northern Rhodesia. Servants then were in the foreground and the background of their employers' lives. They were everywhere. In this chapter I piece together from scattered sources a historical narrative about domestic servants - the kind of work they did, their employers, the relationship between the two-and about employers' views of servants from around the turn of the last century through the interwar period. In so far as the sources allow me, I also offer glimpses of servants' reactions to their employers and about their activities outside of the work locus in colonial households. My account ignores the earliest years of colonial rule, partly because of lack of sources and partly because of the rough-and-ready nature of life on this expanding frontier, where concerns with household management and domesticity had little meaning. ${ }^{1}$ While the early residents had African menservants, there was no place for African women in the early encounter save as objects to fulfill the most basic sexual needs of the frontiersmen. And there was little place for white women except in missionary households.

My concern in this chapter is to capture how whites, believing in the grandeur of Empire and not far removed ideologically from late Victorian mores and norms-to use the terms of their discourse-reacted to the "wilds" of the "far interior of Darkest Africa" and how they initially sought

1. Northern Rhodesia was administered by the British South Africa Company (BSAC) under a charter from the British Crown, beginning in North Eastern Rhodesia 1893-1894 and in North Western Rhodesia in 1897. Before the BSAC administration, this region was sometimes referred to as Transzambezia. The two separate territories were amalgamated in 1911, and in 1924 the Colonial Office in London took over the administration. I use the term Northern Rhodesia for the entire colonial period, except in situations where a regional reference needs to be specified. 


\section{A Fixture of Colonial Society}

to make Africans, particularly their servants, over in their own image. Colonial whites considered Africans to be members of societies so totally different from their own in social, cultural, and moral outlook that they appeared to be part of the wilds across which they lived scattered, and akin to the local flora and fauna. In the view of a contemporary observer: "in all their actions they are so like animals that I question they have any brains." 2 In domestic service, Africans were to become domesticated. To socialize Africans for subordinate roles in white households in the new political and economic order, colonial employers instituted a hierarchical labor process that accentuated the difference between themselves and their workers. In the discourse that accounted for this difference, race, class, and sex converged in complex ways confounded by notions of the other as primitive, tribal, dirty, and mentally inferior. As I demonstrate in subsequent chapters, these factors converged in varying patterns over time, and in unlike ways for the two sexes, thus constructing gender images of the other that never remained completely static.

During the period covered in this chapter, three generations confronted each other as servants and masters: from the turn of the century through World War I; the 1920s and early 1930s into the Great Depression; and the remainder of the interwar period. I examine how Africans were domesticated, so to speak. Kaffirs, like cattle, had to be worked and handled. ${ }^{3}$ They had to be taught the domestic arts in the manner of whites, first by men, for few white women lived there during the earliest part of this period. In Northern Rhodesia, domestic service became constructed predominantly in African male gender terms. (The question of women in domestic service is taken up in Chapter 3. It suffices here simply to note that after the arrival of more white women, eyebrows were raised when colonial officials, most of whom were bachelors during their first tour of office, employed African women as domestics. $)^{4}$

There are three points to make before I begin. First, because of the unevenness of my sources, my account probably does not convey the full range of domestic service employment practices. I have found no information on the servant-master relationship during this period in Afrikaansspeaking households, or in Asian or African domestic arrangements. My account focuses predominantly on the urban end of colonial society and

2. D. D. Lyell, Hunting Trips in Northern Rhodesia, with Accounts of Sport and Travel in Nyasaland and Portuguese East Africa, and also Notes on the Game Animals and Their Distribution (London: Horace Cox, 1910), p. 98.

3. This statement paraphrases a job advertisement inserted by H. G. Koch of Kalomo in the Livingstone Mail, December 18, 1909: "White man to work on farm; must know how to work Kaffirs and cattle."

4. Roy Stokes, personal communication, December 18, 1983. 
ignores white farming households and missionary establishments in the rural areas.

Second, the dynamics I seek to reveal throughout this book are the products of a complex intertwining of three systems of stratification: by race, gender, and class. Since race to a great extent masked class relations during the period under review in the book's first part, the effect of my overall concern is to deemphasize variation among the employing classes and to focus on the governing race: the British. The fact that some African, Asian, and Afrikaans-speaking households also employed servants does not mean that the master-servant relationship in British households was atypical or out of the ordinary. After all, this was the time of Rule Britannia, the British considered themselves the dominant race, and they set the norms and standards against which other practices were evaluated.

Third, because I am concerned to unravel the changing effects of race, gender, and class on the domestic service institution, my presentation tends to revolve around instances of whites dominating Africans and one sex lording over the other. This emphasis may be contrary to the observations of some individuals who were participants in the colonial situation and who have praised the creation of bonds of trust and personal friendships between themselves and their servants. To be sure, feelings of affect and compassion developed in some cases, after a fashion, that is, for the distance between the white master and the black servant in the colonial situation remained too wide in class and cultural terms for genuine friendship with equal participation and shared authority to develop. Whether or not one liked a servant, he was a distant companion. He remained a servant and thus an inferior.

\section{Servants and Other Inventory}

The published literature on Northern Rhodesia readily leaves the impression that contract migrant labor to farms and mines was the only, or main, form of wage labor which developed during the colonial period in this region. Yet from the earliest days of white entry into what became known as Northern Rhodesia, two other forms of labor placed African men at the disposition of white employers: porterage and personal service.

Till the coming of the South Africa-based railway that bridged the Zambezi River in 1905 and reached Katanga in the Congo in 1910, if not till the advent of motor transportation in the 1920s, porterage is likely to have offered the largest employment avenue for Africans within the territory itself, yet on an intermittent, mostly dry-season, basis. Before the railway reached Katanga, the town of Broken Hill, where zinc and lead had been 


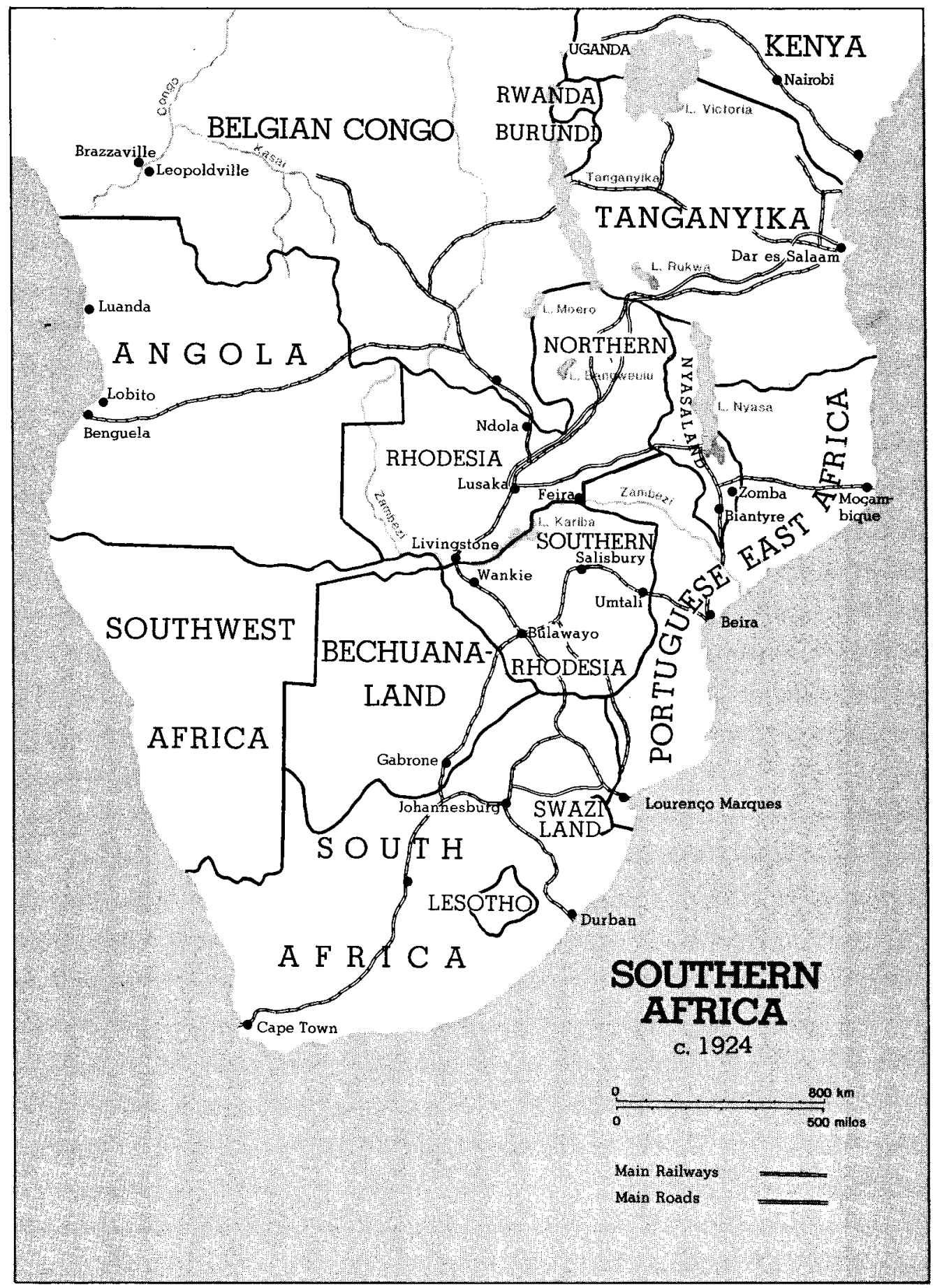

Map 1. 
mined since 1902, served as the railhead for the Congo and the small mines in the Ndola and Kasempa districts. This town was the center for a number of private transport companies. In 1908 they employed a total of 27,818 carriers to transport cargo and passengers. ${ }^{5}$ As more whites took up farming, especially after the Boer War, the need for African farm workers and domestic servants grew. Up to and including the World War I years, African farmhands outnumbered those employed in domestic service. By 1930, more Africans were employed as servants than as farm workers, and only for a brief period during the postwar years did farm workers again outnumber servants. Large numbers of Northern Rhodesian Africans worked on farms, in mines, and in private households in the south and in Katanga in the north and had done so since before the turn of the century. But domestic service was one of the chief avenues for African employment within the territory itself until mining was begun on a large scale in the north in the late 1920s.

The men who entered domestic service had left their villages to earn money for taxes that had been introduced across the territory, in some regions just before and in others just after the turn of the century. ${ }^{6}$ Some of these men must have chosen domestic service in preference to being recruited for contract migrant labor in the south; others proceded on their own to the generally better-paying jobs in the south. Still others shuttled back and forth between jobs within the territory and outside it. ${ }^{7}$ Given the grim work conditions on farms and mines, domestic service is likely to have been a choice favored by many.

Some of these African men had been introduced to service in missionary households where they were taught cleaning, washing, ironing, and cooking in the manner of the whites. Among them were some of the first Christian converts. But many left the mission stations, disliking the coercive regimes. ${ }^{8}$ Others were socialized into domestic service in the households of the tiny but slowly growing white population-among whom a

5. Michael Gelfand, Northern Rhodesia in the Days of the Charter: A Medical and Social Study 1878-1924 (Oxford: Basil Blackwell, 1961), p. 115.

6. For general historical background, see Lewis H. Gann, A History of Northern Rhodesia: Early Days to 1953 (New York: Humanities Press, 1964), and Andrew Roberts, A History of Zambia (New York: Africana Publishing Company, 1976).

7. Charles van Onselen has shown how migrants sought to make the most out of their economic misfortune. The most successful worked their way by stages from the lowest-paid jobs on farms and mines in Southern Rhodesia to the less lowly paid jobs on the Rand. Chibaro: African Mine Labour in Southern Rhodesia, 1900-1933 (London: Pluto Press, 1976). Many Africans, including servants, from Northern Rhodesia also migrated in stepwise fashion.

8. Robert I. Rotberg, Christian Missionaries and the Creation of Northern Rhodesia, 1880-1924 (Princeton: Princeton University Press, 1965), pp. 42, 52-55. 


\section{A Fixture of Colonial Society}

disproportionate number were bachelors ${ }^{9}$-in the small administrative headquarters and on farms scattered across the territory. And still others were taken on as personal servants or cooks in caravans that made their way through the territory to enjoy the sport-meaning big game huntingexplore the wilds, or a combination thereof.

The labor process that evolved in caravan service and private households shared little with what variously has been labeled dependent labor, servitude, or slavery as previously practiced in many societies in this region. ${ }^{10}$ Such practices did not exclude dependent workers from the groups for whom they labored. They had less status, but there were mutual obligations between them and the persons who enjoyed their services. The colonial labor process depended on commoditization of labor. In it, status was exchanged for contract and obligations toward a worker were stipulated in return for rights: the employer's demand for the worker's labor power.

Information about this employment relationship during the early decades of this century may be gleaned from travel descriptions, local memoirs, and reminiscences and should be used with caution. Cairns, using the literature from 1840-1890, warns readers "to make a deliberate effort to not see Central Africa as an arena where all the important activities were carried out by a growing handful of Europeans in the midst of an environment in which Africans, elephants and natural obstacles are lumped together as background landscape."11

Most books of this period, whether travel accounts or memoirs, contain advice to travelers and prospective settlers. Sometimes in the form of an

9. Because of climatic vagaries and the risks of malaria, sleeping sickness, yellow fewer, and other tropical diseases, Northern Rhodesia was known as the "white man's grave," and it was not till after World War I that white women began to arrive in larger numbers. For a discussion of illness and health during the period of early settlement, see Gelfand, Northern Rhodesia. See also Table 3 in Chapter 2 below for sex ratios.

10. In African studies, the term slavery comprises a variety of relationships. In recent work on the subject, Robertson and Klein note that slavery "has been variously defined in terms of property relationships . . . or in terms of the slave's kinlessness. Whatever definition is used, the slave is involuntarily servile, has a marginal position within [the] social unit, and is subject to the control of others." Claire C. Robertson and Martin A. Klein, eds., Women and Slavery in Africa (Madison: University of Wisconsin Press, 1983), pp. 3-4. For a comparative discussion of slavery in Africa, see Suzanne Miers and Igor Kopytoff, eds., Slavery in Africa: Historical and Anthropological Perspectives (Madison: University of Wisconsin Press, 1977). Cross-cultural comparisons of African and Asian slavery are available in James L. Watson, ed., Asian and African Systems of Slavery (Berkeley: University of California Press, 1980). For other Central African examples, see Mary Douglas, "Matriliny and Pawnship in Central Africa, Africa 34 (1964): 301-313; Arthur Tuden, "Slavery and Social Stratification among the Ila of Central Africa," in Social Strattfication in Africa, ed. A. Tuden and L. Plotnikov (New York: Free Press, 1970), pp. 47-59; and Marcia Wright, Women in Peril: Life Stories of Four Captives (Lusaka: NECZAM, 1984).

11. J. Alan Cairns, Prelude to Imperialism: British Reactions to Central African Society, 1840-1890 (London: Routledge and Kegan Paul, 1965), p. 30. 


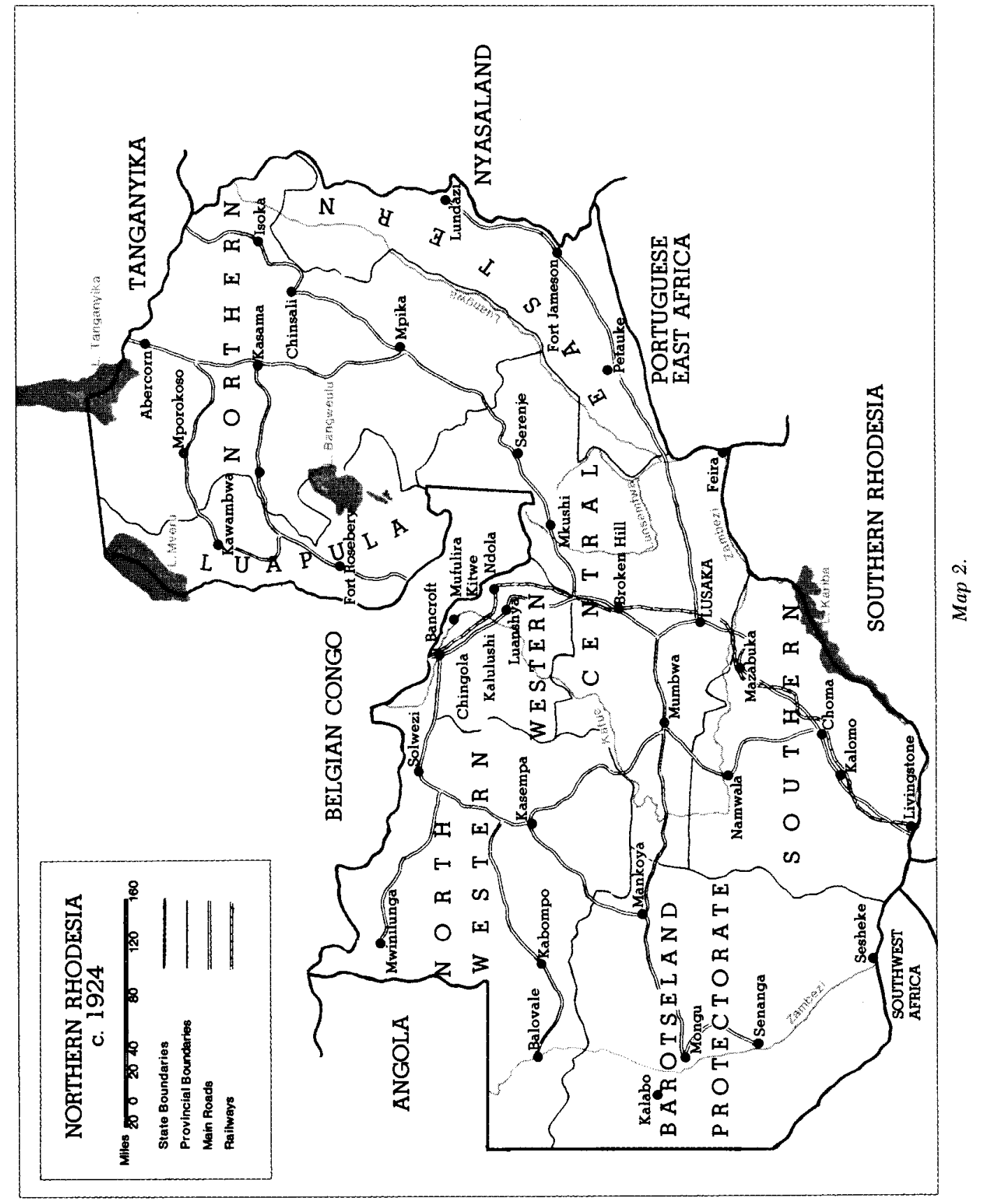




\section{A Fixture of Colonial Society}

appendix, in other cases merely as prescriptive remarks thrown in, these accounts offer an inventory of items and provisions to bring from overseas and advice about items locally obtainable. Porters and servants were part of the local inventory and readers were told which brands (e.g., different tribes; raw natives versus mission boys) were better or worse, how to deal with them in terms of remuneration and food, and what to expect, or rather not to expect, of them in terms of work discipline. ${ }^{12}$ These early travelers moved on foot and/or were carried in machilas (hammocks). ${ }^{13}$ (Horses and ox wagons were of little use in the territory north of the Zambezi because of the tsetse fly.) Others journeyed on bicycles. ${ }^{14}$ During the 1920 s automobiles appeared, ${ }^{15}$ yet in outlying districts, feet, machilas, and bicycles, or a combination, remained in use much longer.

The travelers' experiences in this remote interior, delivered in books with expansive titles, display a self-confidence bordering on arrogance, rooted in late Victorian mores and habits and in the knowledge that Europe, if not Britain, was the center of the world and the standard against which everything else was measured. Among them Mary Hall, a young British woman of means who had traveled "all the great continents of the world," accounted for how she was the first woman who "quite alone" managed to complete the trek from Cape to Cairo soon after the turn of the century. ${ }^{16}$ Mrs. Arthur Colville described what it was like to cross from Chinde in Portuguese East Africa to the interior of Northern Rhodesia in a machila in 1908-1909, while her colonel husband, of fame from the Kabarega campaign in Uganda, described the sport. ${ }^{17}$ About the same time, a young British novelist, Charlotte Mansfield, traveled in machila through

12. For a classic of this genre, see Sir Francis Galton, The Art of Travel, or Shifts and Contrivances Available in Wild Countries (1854; London: John Murray, 1893), which appeared in at least eight editions. The book contains a special section on "management of Savages" (pp. 308-310). For an example from this region, see the chapter entitled "Some Native Traits" in Lyell, Hunting Trips, pp. 98-101, and the chapter entitled "Odds and Ends of Information" in his later book, Nyasaland for the Hunter and Settler (London: Horace Cox, 1912), pp. 89-90. His contemporary Owen Letcher in Big Game Hunting in North-Eastern Rhodesia (London: John Long, 1911) also included an inventory chapter with information for visitors and sportsmen, entitled "The Natives of the Country, and some Questions Affecting Them."

13. Mrs. Arthur (Olivia) Colville, One Thousand Miles in a Machila: Travel and Sport in Nyasaland, Angoniland, and Rhodesia, with Some Account of the Resources of These Countries; and Chapters on Sport by Colonel Colville, C. B. (London: Walter Scott Publishing Company, 1911).

14. Frank H. Melland and Edward H. Cholmeley, Through the Heart of Africa: Being an Account of a Journey on Bicycles and on Foot from Northern Rhodesia, Past the Great Lakes, to Egypt, Undertaken when Proceding Home on Leave in 1910 (London: Constable, 1912).

15. Selma Whitehouse, Moonlight, Giraffes, and Frying Pans (London: John Lane, 1928), describes the first automobile trip from Johannesburg through Northern Rhodesia.

16. Mary Hall, A Woman's Trek from the Cape to Cairo (London: Methuen, 1907).

17. Colville, One Thousand Miles. 
the small towns and administrative stations of Northern Rhodesia. ${ }^{18}$ And self-proclaimed suffragette Edith Cecil-Porch, in a book she authored under her later husband's name, described the recruitment of travel companions in England for a trip beyond the Zambezi to see the world and to seek adventure. ${ }^{19}$ In these books and others like them Africa and Africans are depicted, much as Cairns suggested, mostly as backdrops against which fairly rich whites went out to play.

A caravan was much like a traveling village. Mary Hall's feeling of being "quite alone" was thus an experience of racial and cultural difference between herself and the retinue of porters and servants. A typical retinue would consist of ten to twelve men to carry the machila. (The hammock covered with a canopy was swung either on one pole or on two parallel poles and carried by two or four men on their shoulders. They would be relieved by others after a short while, the pole being changed from one man's shoulder to his replacement's while running. $)^{20}$ Large numbers of porters carried provisions and equipment in headloads of standard weights, varying regionally from thirty to sixty pounds, under the supervision of a head porter, referred to as capitao. The number of porters per passenger ranged between twelve and thirty. ${ }^{21}$ The suffragette's party of four employed fifty porters. ${ }^{22}$ Last but not least came the personal staff, consisting perhaps of cook, tableboy, plate washer, and sometimes a personal boy. Local whites would be equipped in much the same fashion when on ulendo (bush travel), though the number of porters and servants might be somewhat smaller. ${ }^{23}$

Porters and servants were engaged often with the help of local officials at the major transportation centers: Fort Jameson in the east, Abercorn in the northeast, Livingstone in the south, and Broken Hill on the railway line. The length of their journey, weight of loads, and remuneration were agreed on in advance. If a personal servant misbehaved or absconded en route, he was often replaced by a porter who received on-the-job training for service.

18. Charlotte Mansfield, Via Rhodesia: A Journey through South Africa (London: Stanley Paul, n.d., ca. 1909).

19. Mrs. Fred Maturin (Edith Cecil-Porch), Adventures beyond the Zambezi of the O'Flaherty, The Insular Miss, the Soldier Man, and the Rebel Woman (London: Eveleigh Nash, 1913).

20. J. M. Moubray, In Central Africa: Being an Account of Some of the Experiences and Journeys of the Author during a Stay of Six Years in That Country (London: Constable, 1912), p. 46.

21. Gelfand, Northern Rhodesia, p. 115.

22. Maturin, Adventures, p. 22.

23. For descriptions of ulendos by early officials, see various articles in the Northern Rhodesia Journal, among them E. Knowles Jordan, "Feira in 1919-1920," 4 (1959): 63-71, and "Chinsali in 1920-1922," 5 (1964): 540-548. 


\section{A Fixture of Colonial Society}

Much of the personal staff and the machila men had servants to carry their travel kits and see to their comforts. ${ }^{24}$ The "cook [was] a man of dignity and carrie[d] only himself." 25 The matter of the servants' servants caused the travelers some surprise. They seemed to appear out of nowhere, suddenly being part of the caravan. ${ }^{26}$ In addition, though not so often commented on by the travelers of the early part of this century, Africans from the various localities traversed by the caravan often attached themselves to it, sloughing off between the villages. ${ }^{27}$ Among them also were women who cooked and provided sexual services to the African staff as well as to white men who traveled unaccompanied by women. ${ }^{28}$

Personal servants mediated many contacts among the travelers, the rest of the retinue, and the local Africans. Because travelers rarely spoke any local languages, some found it useful to employ mission boys who had learned some English. When reaching Nyasaland from South Africa, Mary Hall needed a servant who could speak English and Swahili. She hired Robertson, one of the "native pupil teachers" at the Church of Scotland Mission in Blantyre, who accompanied her to Tanganyika as her sole interpreter. ${ }^{29}$ Colonel and Mrs. Colville engaged a man named Moffat as cook. He had also gone to school at the Blantyre mission, and Mrs. Colville described him as a first-rate servant and a good cook. But in the prescriptive remarks to other travelers or settlers, her position changed: "his spurious education destroys his simple nature, and in some cases he degenerates offensively in his manners." 30 This remark may reflect the received wisdom on servants which the Colvilles picked up along the way. Many employers were wary of mission boys, whose smattering of education was held to make them less respectful to whites. Because they had been Christianized and/or educated, mission-trained men were perhaps less different from the whites; they may have caused problems of discipline by asking too many questions. "If he can possibly help it," commented J. M. Moubray, a mining engineer who traveled throughout the territory between 1903 and 1908 , "the white man will never employ a mission boy . . . many [of whom]

24. Moubray, In Central Africa, p. 47.

25. Mansfield, Via Rhodesia, p. 177.

26. Maturin, Adventures, pp. 27-28, 271-272.

27. Dugald Campbell, In the Heart of Bantuland: A Record of Twenty-nine Years' Pioneering in Central Africa among the Bantu Peoples with a Description of Their Habits, Customs, Secret Societies, and Languages (1922; New York: Negro Universities Press, 1969), p. 278.

28. Instances of sexual relations between white travelers and African women were frequently reported in the travel/exploration literature from before the turn of the last century but seem to have been filtered out of this era's descriptions. See Chapter 3 for more discussion of sexuality and race.

29. Hall, Woman's Trek, p. 53.

30. Colville, One Thousand Miles, pp. 19, 20, 303. 
are rogues of the first water." "My own natives," he continued, "by which I mean my personal boys and hunters ... were aliens." He preferred Yao men from Nyasaland. ${ }^{31}$

In hiring servants, many travelers and settlers preferred nonlocal men. And travelers made observations about the "good" boys from foreign territories when they stopped to visit resident whites. When making up their inventory in Nyasaland before setting out on their machila trek, the Colvilles hired Edward, from Chinde in Portuguese East Africa, as a personal servant. ${ }^{32}$ Edith Cecil-Porch's party engaged a servant staff of four Tanganyika boys at Livingstone, among them her future husband's headman, interpreter, and body servant in one. Hymn-book, as they called him, was a Christian, "which, if anything, rather set us against him." 33 The BSAC clerk at Kalomo before 1911, E. Knowles Jordan, also hired two Tanganyika boys. ${ }^{34}$ When visiting Kalomo in 1903, then the capital of North Western Rhodesia, Lady Sarah Wilson commented on the work of the servants: "I was much impressed in a Kalomo house with the small details of a carefully arranged dinner table, adorned with flowers and snowy linen; the cooking was entirely done by black boys, of these the 'Chinde' boys from the Portuguese settlement are much sought after, so thoroughly do the Portuguese understand the training of natives." 35

But more so than any others, Nyasa boys were said to be good in Northern Rhodesia. ${ }^{36} \mathrm{~A}$ stereotypic preference has remained to the present day in Zambia for servants, if not from Malawi, then from Zambia's eastern province, which borders on Malawi. In Southern Rhodesia in turn, whites preferred northern natives, Nyasa, and Chinde boys. ${ }^{37}$ And in South Af-

31. Moubray, In Central Africa, p. 34

32. Colville, One Thousand Miles, p. 20.

33. Maturin, Adventures, p. 20.

34. E. Knowles Jordan, "Early Days in Kalomo and Livingstone," Northern Rhodesia Journal 1 (1950): 21.

35. Sarah Wilson (Lady Spencer-Churchill), South African Memoirs: Social, Warlike, and Sporting: From Diaries Written at the Time (London: Edward Arnold, 1909).

36. John B. Thornhill, Adventures in Africa: Under the British, Belgian, and Portuguese Flag (London: John Murray, 1915), p. 10.

37. The preference for "northern natives" in domestic service is mentioned in Ethel Tawse Jollie's The Real Rhodesia (London: Hutchinson, 1924), a book akin to a household management guide, displaying white settler ideology. The smart Northern Rhodesian servant is idealized in Gertrude Page's novels set in Southern Rhodesia before World War I. Among them are Jill's Rhodesian Philosophy (London: Hurst and Blacckett, 1910); The Rhodesian (London: Hurst and Blackett, 1912); Where the Strange Roads Go Down (London: Hurst and Blackett, 1913); Follow After (London: Hurst and Blackett, 1921); and Love in the Wilderness (London: G. Bell and Sons, 1907). The preference for servants from Portuguese East Africa is noted by Hugh M. Hole, a writer of settler history and once civil commissioner of Bulawayo. According to Hole, the indigenous Mashona were not of any value as cooks, wagon boys, farm or mine laborers. "For domestic purposes, we selected mainly boys imported from the territories on the East coast, where they had long been accustomed to work for the slothful Por- 


\section{A Fixture of Colonial Society}

rica, the northern boys had a very fine reputation. Wherever they were, employers thus seem to have preferred nonlocal servants. The tour reports written by colonial administrators in Northern Rhodesia are replete with statements on the order of "local natives make bad servants." In 1919, for instance, in Chilanga subdistrict, which included the small town of Lusaka, the great majority of African wage laborers were from other parts of the territory or Nyasaland. The subdistrict then had a total white population of 576, of whom 217 were men, 129 women, and 230 children. More than half of them were Afrikaans-speaking South Africans, and about half of the adult male population were farmers. The African labor force consisted of 1,300 men, of whom 300 worked as servants and 650 as farm laborers. The rest worked on the small mines, in quarries, on the railways, or as capitaos. An additional 700 men were employed by the administration and 284 carriers were supplied for war-related work in the north. ${ }^{38}$

The 300 servants in the Chilanga subdistrict in 1919 came from two principal regions: Nyasaland and the north. ${ }^{39}$ The tour report lists the latter as Bemba, yet they are likely to have included some Inamwanga, neighbors of the Bemba who lived on both sides of the border between Northern Rhodesia and Tanganyika. They may have been among the Tanganyika boys mentioned earlier. The men who came from afar had left behind wives and dependents. Local Africans did not turn up readily for farm work or for domestic service. If they could make a living in their villages, they seem to have preferred that. When they did take on wage labor jobs, they were likely to have had too many conflicting claims placed on their labor and time by relatives from the home villages. This may have adversely affected their constancy in wage labor and helped to bring about the high turnover rates about which white employers complained as well as the preference for nonlocal workers.

For their work, servants were paid in cash and kind. The latter, known as posho or ration, seems to have consisted of cloth, at least during the first decade of this century. Arriving by train at the railhead at Broken Hill in

tuguese employers, and had become fairly efficient as house servants." Old Rhodesian Days (London: MacMillan, 1928), p. 46. He also mentioned that while many servants were from the east coast, others came from more distant parts: Zulus from Natal, mission boys from Blantyre in Nyasaland, and even some from as far as Uganda. They were all, according to his account, attracted by the high rates of pay, based on "the South African scale" (p. 5l).

38. NAZ/KDC 6/1/6. Annual Reports, Chilanga Subdistrict, Luangwa District, 19171928. Annual Report for the Year Ending March 31, 1918.

39. Ibid. Annual Report for the Year Ending March 31, 1919, which gives the following ethnic/regional division of labor among Africans employed in the subdistrict: cattle herds: Barotse or Mashukulumbwe; wagon drivers and plough boys: South Africa or Barotseland; houseservants and cooks: Fort Jameson, Wemba Division, and Nyasaland; sawyers, carpenters, bricklayers: Nyasaland; farm laborers: Mumbwa, Namwala, and Kasempa; railway laborers: Mkushi, Ndola, Mwomboshi; Fishermen and canoe boys: Wata from Namwala. 
1906 after five years in Southern Rhodesia, John M. Springer, an American Methodist missionary, and his wife provisioned their caravan for a trek to Luanda at the Atlantic coast, noting the "good custom for rationing a caravan. Each man is given a yard of blue or white calico, and he buys his food for a week with it. . . In addition, we gave our men two ounces of salt each week." 40 When crossing from Nyasaland, where they had paid full cash wages, into North Eastern Rhodesia in 1908, the Colvilles also remarked on the change in remuneration. For in North Eastern Rhodesia posho had to be paid in calico, two yards per man per week. Small amounts of salt were also handed out. From there on, three posho loads were added to their caravan: one of calico and two of salt, the latter to be used as currency in the interior. ${ }^{41}$ In addition to the rise in remuneration, there was also regional variation. On the North Eastern plateau, according to Cullen Gouldsbury and Hubert Sheane, posho consisted of four yards of calico per month-this, as in the previous cases, in addition to cash wages. ${ }^{42}$

Travelers' accounts show less concern with the socialization of servants than do those given by white residents. After all, travelers were in transit and not out to carve out small islands of white civilization for themselves. Their comments about servants may perhaps be somewhat exaggerated because they were unprepared for the stark difference between life as they knew it at home and their experience of it in what they considered the wilds beyond the Zambezi. On the other hand, some of their descriptions offer glimpses of servants at very close range.

Women writers, in particular, frequently commented on servants. The carriers' and servants' "domestic affairs afforded constant interest" to Edith Cecil-Porch when she rested in camp while her two white men companions pursued the sport. She commented on the blasé attitude of the smartly attired personal servants toward the half-naked carriers, their separate sleeping arrangements, the division of labor in the caravan kitchen where the cook's "slaves" did the main part of the work, and on the "brudders" and the women who hung around the camp kitchen when the caravan made stops. Her musings are sometimes quite negative, for example, when she called all the servants "perfidious" for giving the same lame excuse-the death of a relative-when one morning they turned up unable to work after a night of drinking in a nearby village. 43

But on one matter there was no mincing of words: the cook was good. In fact, most travelers were very impressed with the skills of their cooks, who

40. John Mckendree Springer, The Heart of Central Africa: Mineral Wealth and Missionary Opportunity (New York: Jennings and Graham, 1909), p. 79.

41. Colville, One Thousand Miles, pp. 129, 173-174.

42. Cullen Gouldsbury and Hubert Sheane, The Great Plateau of Northern Rhodesia: Being Some Impressions of the Tanganyika Plateau (London: Edward Arnold, 1911), p. 323.

43. Maturin, Adventures, pp. 21-22, 27, 100, 328-329. 


\section{A Fixture of Colonial Society}

managed to prepare courses of several dishes, using mainly tinned foodstuffs carried along in the loads, and chickens, eggs, vegetables, and fish bought from local Africans. If there were white men in the party, game shot en route was cooked as well. Fresh bread was baked daily on many caravans. The Springer's cook, a mission boy brought from Umtali in Southern Rhodesia to Luanda "was the best fitted of all the boys to fill the role of helper, interpreter, and general man. . . He was also a splendid cook and had the art of a superior chef-the ability to make tasty dishes out of almost nothing." 44 While on trek, although in the wilds, life was not necessarily simple. Some, like Colonel and Mrs. Colville, traveled in style. They shared an imperial pint of champagne twice a week, and on other nights they drank whiskey and sparklet, with a glass of Madeira after dinner. ${ }^{45}$

Because personal servants ministered to the daily needs and comforts of their traveling employers, they came into contact with them more frequently than did other Africans in the caravans. Nevertheless in the eyes of their employers, servants remained just that: part of an inventory, distant companions. Whatever else the servants did as individuals was of little consequence to their employers so long as it did not interfere with the execution of their work. At most, drunken brawls annoyed the employers, and the pecking order among servants and carriers amused them. These two aspects of the personal affairs of the African staff seem to have been the main ones noted by the travelers. Not the private life, background, or idiosyncracies of servants as individuals but their habits, spoken of collectively, of drinking, gambling, and consorting with women.

It simultaneously amused and annoyed the whites to notice how much their personal servants liked to dress up European-style. They were amused by the ill-matched garments and annoyed because the welldressed African appeared less like a piece of inventory and more like a white. Almost without exception, travelers' accounts contain comments to that effect. In the words of Mrs. Collville: "The black man is essentially vain. There can be no doubt that the wearing of European clothes in his own hot climate has an extraordinary and deteriorating effect on his mind. Dressed up in the cast-off clothes of his master, or the shoddy garments of the native store, he really think he impersonates and is on a level with a white man. . . . It is a great pity stringent rules are not made to prevent natives from apeing the white man's dress, especially in a young colony. ${ }^{46}$

Such contempt for African attempts to dress in style also reflected the attitude of white residents. Consider the sarcastic evaluation of such efforts

44. Springer, Heart of Central Africa, p. 59.

45. Colville, One Thousand Miles, p. 40.

46. Ibid., p. 133. 
in the following note, from which we can glimpse an occupational culture in the making among servants in Livingstone in 1909:

Last week a gentleman requiring his evening clothes found the coat missing. On questioning his boy the latter fetched the garment from his $k[a] y a$ [hut]. Investigation revealed he had worn it the previous evening at a dinner party given by some of his friends to their acquaintances of both sexes. Subsequent inquiries [revealed] ... that other peoples' clothes were missing. . . . A native dinner party, with the gentlemen attired in evening dress, stand-up collars, white vests, and possibly patent leather shoes, the ladies being doubtless "en decollette" must have been an inspiring sight, and the fact that such a function has been successfully held is . . . evidence of the rapid advance of civilization. ${ }^{47}$

The conments by this Livingstone resident ignore almost completely any serious reckoning with the functions that European dress may have played in the social lives of servants when away from work. The story, whether true or false, had a sorry ending, for the chief actors received several strokes of the cane.

The travelers also commented on the lifestyle of the resident whites they visited in the tiny settlements. Against the background of what the travelers considered as the wilds, The Society appeared as small islands of civilization. Since there were few visitors, local whites were very welcoming and opened their homes to entertain up-country shooting parties, ladies of fame, and people of means bent on enterprise. Lady Sarah Wilson (Spencer Churchill) was impressed by the emptiness and youth of the territory when she visited Livingstone and Kalomo in 1903.48 The white population was estimated to number only 850 in 1904, and 1,497 at the time of the first census in 1911 when the African population stood at some $820,985 .{ }^{49}$ In this vast territory in which the visitors saw so many economic potentials, they noted "one draw-back ... there are not enough [white] women." Dinner parties consisted of eight men to two women in North Western Rhodesia, wrote novelist Catherine Mansfield after her visit around 1908/9.50 In 1911, white men outnumbered white women by three to one. ${ }^{51}$ Miss Mansfield commented: "the [white] inhabitants are ambitious and surprisingly up to date in their ideas. . . The officials are

47. "Notes and Memos," Livingstone Mail, February 9, 1909, p. 6.

48. Wilson, South African Memoirs, p. 303.

49. George Kay, A Social Geography of Zambia (London: University of London Press, 1967), p. 26. The African population figures are taken from NAZ/BS 2/134. BSAC Administration. Annual Reports, North Western Rhodesia, 1911, and North Eastern Rhodesia, 1911.

50. Mansfield, Via Rhodesia, p. 142.

51. Kay, Social Geography, p. 26. 


\section{A Fixture of Colonial Society}

cultured men and their wives charming women" (italics added). She was entertained in style: a garden party hosted in her honor by the wife of Administrator Wallace at Livingstone, with more than seventy guests for tea on the verandah while "a native band of drums and fifes discoursed music on the lawns below." The mine officials at Broken Hill declared half a day's holiday at which she entertained them; there was piano playing and singing, and the local magistrate was the best banjo player she had heard off the professional platform. ${ }^{52}$ In the life of resident whites "sport is naturally at present the chief pastime. . . Everyone reads, many are musical, and conversation has as much and often more interest in than 'the bored talk in European towns. " 53 Such enthusiasm was not shared by all travelers, and not all towns were equally cultured. Lusaka was merely a railway siding that had arisen in 1905 alongside the building of the railroad to the north. It was still a small village when Edith Cecil-Porch's party made a one-week stop in 1913, and its population was predominantly of Afrikaans-speaking background. In addition to being unpleasant, the place was boring. Comments Miss Cecil-Porch: "I can't think of how they faced life, for it had none of the compensations of ours . . practically no society, no pleasures, nothing!"54

Few texts from the days of frontier life describe how unmarried white men went about the practical tasks of tropical housekeeping. Many, as I discuss in the next chapter, took African wives who may have carried out part of the housework. Yet Heaton Nicholls, a BSAC official, reports that when he and a white colleague trekked from Southern Rhodesia to the Kafue Flats in Northern Rhodesia to take up a new assignment, they "tried [their] hands at cooking with the aid of Mrs. Beeton's cookery book and by substituting for her ingredients anything available." 55 I doubt that they did the regular cooking. Their caravan is likely to have included a cook and perhaps a personal servant in its inventory.

As most other texts, Nicholls's autobiography offers no glimpses of how

52. Mansfield, Via Rhodesia, pp. 142-144, 164-165.

53. Ibid., p. 142. Miss Mansfield's book was commented on extensively in the local press by two writers who took her to task, not for her descriptions of The Society, but for exaggerating the wildness of her exploits. They pointed out, among several other things, that she hardly traveled unaccompanied; in addition to African servants, she had European male escort at several points of the journey; she did not trek through unexplored parts but followed welltrodden routes that other white women had traveled before her; and she traveled most of the route from the Cape to Cairo not overland but whenever possible by railways, gunboats, and steamers. Miss Mansfield's Africa is thus a constructed product, her descriptions of the extensive wilderness and the small islands of white civilization in the colony meant for consumption by readers in Great Britain. "John Bull' and Miss Mansfield," Livingstone Mail, October 2, 1909, p. 4, and "Cape to Cairo," Livingstone Mail, November 13, 1909, p. 2.

54. Maturin, Adventures, p. 385.

55. G. Heaton Nicholls, South Africa in My Time (London: Allen and Unwin, 1961), p. 52 . 
servants were domesticated into their work roles by white men living without permanent female company, black or white. The men I spoke to or corresponded with, who came to Northern Rhodesia in the late 1920s, typically had a servant referred to them by an old-hand on their arrival to Livingstone or Lusaka. Some of these servants accompanied them to upcountry posts, but others vanished, not willing to relocate to a different language area. At bush stations, wives of missionaries or officials subsequently recommended servants. James Murray had employed a cook, Chongo, recommended by missionaries near Mkushi in 1929. When he became district commissioner at Mkushi in 1934, he "decided to import a wife. She soon discovered that my monthly consumption of sugar, flour, ... soap and tea were enough for a boarding house and Chongo's hours of work were drastically increased. There was no time off between 8 and 12 , there was much dusting, floor polishing to be done and more or less endless washing of . . . table cloths and even dish cloths. Puddings had to be made for lunch and supper and there was interference in the kitchen. Chongo naturally left." 56 By contrast, when Gervas Clay in 1936 brought his wife, Betty, to Barotseland where he had been stationed since 1930, the cook stayed put. Clay engaged him upon the recommendation of the wife of the local district commissioner. Betty left things to the cook without much interfering. As the youngest daughter of Lord Baden Powell, she had little practical experience in housework and the cook in all likelihood introduced her to tropical housekeeping. When leaving Britain she had no idea of what life in the bush would be like, she told me, but retrospectively and with good-scouting attitude, she spoke of it as adventure and excitement. The cook stayed with them till he died, after which the houseboy was promoted to cook. ${ }^{57}$

If travelers were impressed by the skills of their personal servants, especially their cooks, the few white women settled in the territory at this time had already begun to complain about their domestic trials with servants. Most of them had a fair number, because servants' wages were low and because it was assumed, rightly or wrongly, that Africans were incapable of doing more than a simple job. So there were separate cook, house-, laundry, scullery, wood-, water-, garden boys, and so forth. ${ }^{58}$ Their numbers seem to have ranged from six to twelve. White women faced the task of turning what they called raw natives into domestic workers, skilled at keeping house like in London, under circumstances where many basic amenities were lacking.

56. James Murray, personal communication, October 19, 1986.

57. Betty and Gervas Clay, personal communication, July 5-6, 1986.

58. Robert C. Tredgold, The Rhodesia That Was My Life (London: Allen and Unwin, 1968), p. 16. 


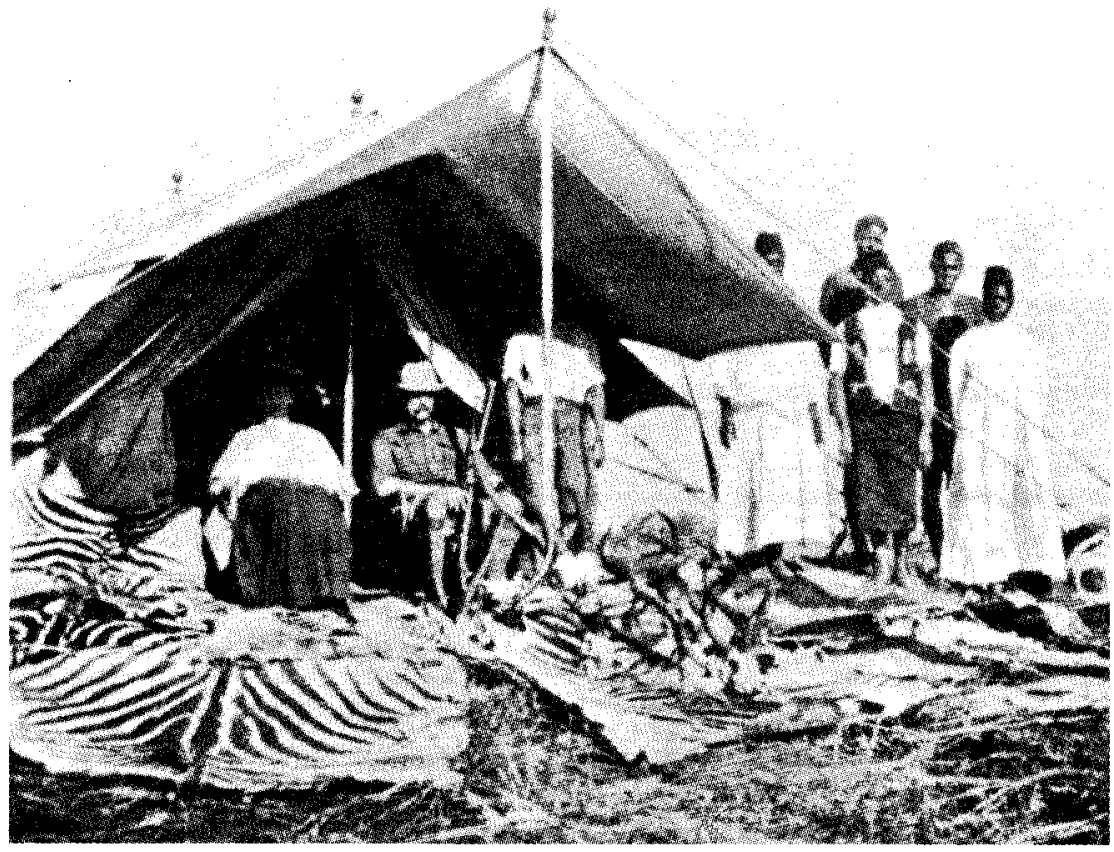

Edith Cecil-Porch, two men companions with trophies, and servants during caravan trek. Reprinted from Mrs. Fred Maturin (Edith Cecil-Porch), Adventures beyond the Zambezi (London: Eveleigh Nash, 1913), p. 384.

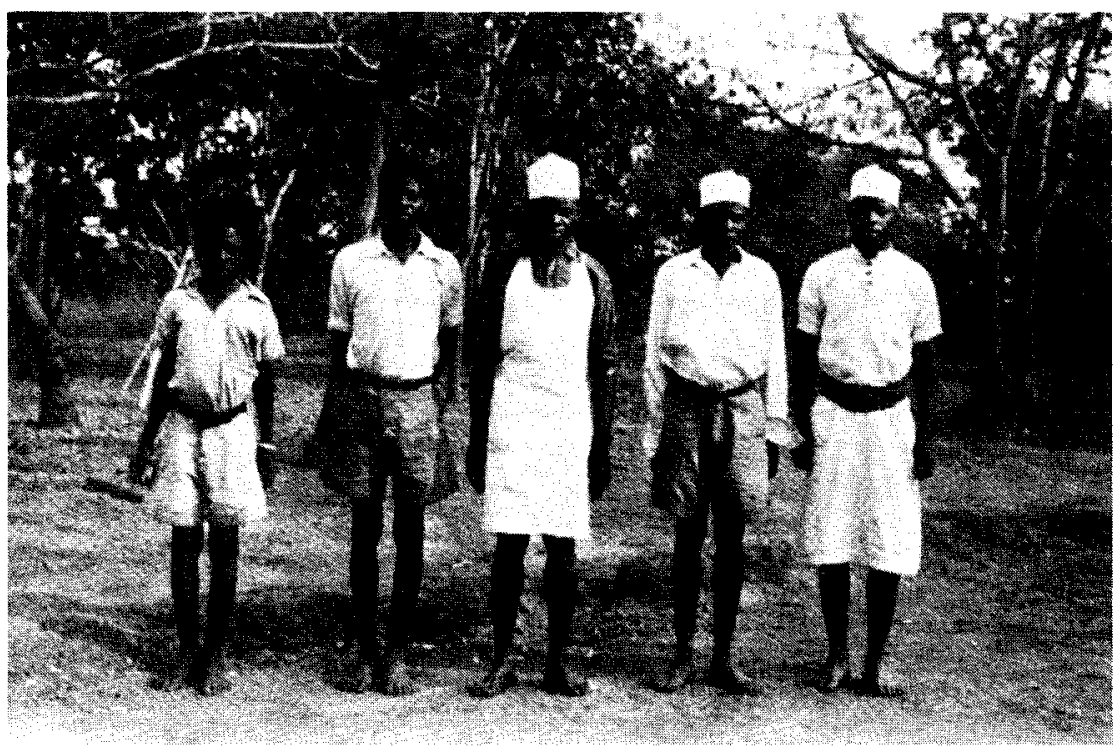

The household staff of S. R. Denny, Kasempa, c. 1930. From left to right, probably: piccanin, washboy, cook, houseboy, and tableboy. Reproduced with permission of S. R. Denny, from photograph deposited in the Bodleian Library at Rhodes House, Oxford University, MSS Afr. s. 791(3). 
Where both husband and wife were present in a colonial household, the man seems to have been more lenient than the woman in evaluation of servants. This at least is the tenor of comments in a 1909 newspaper writeup by one Harold Reynolds:

\begin{abstract}
Why does the native so strongly object to a missus? . . . The Bwana is content to take things as they come. Sometimes he gets angry and his wrath is very terrible, but it is only for a few minutes. . . But the missus is often angry. ... [A] woman tries to teach the native to do things her way. One native in a hundred can learn, but the other ninety-nine must do things in their own way or not at all. . . . Remember, in the degree that you charm so shall be your powers. . . . Do not attempt to teach the native overmuch; realize his limitations, and do not attempt to drill into that wooly head that which its mental capacity cannot possibly grasp. You will only ruin your constitution and your temper. . . . Be your own delightful self and you will perform the whole duty of woman in tropical climes [italics added]. ${ }^{59}$
\end{abstract}

Cullen Gouldsbury, BSAC official on the northeastern plateau in the 1910s, expressed similar sentiments in his semifictional account of domestic life in these parts. While his description of household affairs highlights the indispensability of servants to the effort of creating The Society of the time, he and his wife reacted in very different ways to the household staff. Whereas wife Beryl classified servants by "a standard of smelliness or unsmelliness, or of those who are suitable for housework and those who are not" and when she was in a bad mood viewed the African "instinctively, as a beast," Gouldsbury himself thought that they were an asset who, with education, eventually would advance. ${ }^{60}$

In Gouldsbury's and BSAC colleague Hubert Sheane's 1911 impressionistic account of life on the plateau, servants were an important part of the inventory. Following the conventions of this era, their book includes prescriptive sections. Servants are featured under "ways and means" and readers informed that good servants can be engaged at Zomba and Blantyre in Nyasaland. Boys fill a section of their own and are described as being a matter of taste. The book offers recommendations about how many to employ, in which functions, and at what wages. For the smooth running of the household, one boy should be appointed head servant and have some degree of authority over the rest so as to relieve the master from overseeing everyone. ${ }^{61}$

Some of these servants advanced through the ranks and worked for the same employers for many years. Some masters grew fond of their servants,

59. "At Random," Livingstone Mail, December 25, 1909, p. 6.

60. Cullen Gouldsbury, An African Year (London: Edward Arnold, 1912), pp. 25, 106, 169.

61. Gouldsbury and Sheane, Great Plateau, p. 309, 323-324. 


\section{A Fixture of Colonial Society}

after a fashion, and took them along to see the world. Codrington, an early administrator of North Eastern Rhodesia, once took his favorite boy to England on leave. ${ }^{62}$ Stewart Gore-Browne, later of political fame in Northern Rhodesia, took along two servants, Bulaya and Kakumbi, when he went to England at the beginning of World War I. He wanted them "to see and learn . . . the very best of our things . . . and how we really live. Something to set against the mining towns which [in Northern Rhodesia] is what passes for the height of English habit and living. [He] wanted to educate them and not to spoil them."63 When Gore-Browne left for the front, he made arrangements for Bulaya and Kakumbi's return to Northern Rhodesia. On the morning of their departure, Bulaya had disappeared; only Kakumbi went back and joined Gore-Browne's African staff on his return from the war. Bulaya meanwhile had some menial jobs, then enlisted in the army and spent time in France and Palestine. In 1922 arrangements were made once again for his return to Northern Rhodesia, but he absconded. $\mathrm{He}$ later became an actor and married an Englishwoman. ${ }^{64}$

Some employers took servants along on vacation trips to South Africa. 65 These servants and those of famous men certainly did "see the world," although it is uncertain how they interpreted it and what sort of educational lesson they got from it. Codrington's servant was scared to tears when taken to the hippodrome for entertainment. ${ }^{66}$ And Northern Rhodesian officials viewed Bulaya's self-selected education with suspicion, considering it unwise to encourage his return: "he could hardly be expected to readjust himself to the ordinary conditions of life in a native village, nor could he continue to live like a European in this territory." 67

Other servants used Bulaya's strategy, though on a lesser scale, seeking to make the best out of their restricted opportunities. Many moved from household to household, diversifying their careers with shorter or longer periods of rest in their villages and with other types of jobs inside and especially outside the territory. Those who joined caravans are likely to have moved around in a similar manner. Some might have traveled widely, like Amoni, a Swahili boy "from somewhere below the [Northern] Rhodesian border," who at Kigoma on the eastern shore of Lake Tanganyika

62. Mansfield, Via Rhodesia, p. 147. The administrator was the highest position of local authority during the period of BSAC rule.

63. Robert I. Rotberg, Black Heart: Gore-Brown and the Politics of Multiracial Zambia (Berkeley: University of California Press, 1977), p. 69.

64. Ibid., p. 70 n. 19.

65. This practice is noted in some of ther annual reports, among them NAZ/KDC $6 / 1 / 6$. 1918 and 1919.

66. Mansfield, Via Rhodesia, p. 163.

67. Statement by Governor H. J. S. Stanley to Secretary of State for the Colonies in 1925, cited in Rotberg, Black Heart, p. 70. 
attached himself to the caravan of Colonel Alexander Powell, an inveterate American traveler with a self-proclaimed insatiable curiosity and fascination for savage countries, who in 1924 crossed the continent from coast to coast, accompanied by his wife and a male friend. ${ }^{68}$ Amoni had acquired a sketchy knowledge of English at a mission school and been trained by a British colonial officer in southern Tanganyika in the arts of valeting, laundering, cooking, and waiting on table. When his employers went on leave, he had accompanied them to Dar es Salaam and was returning to his wife and village in Northern Rhodesia, where he would wait until he had to meet them on their return. He had been six weeks en route, walking intermittently with stops of two to three days in villages along the way, when he met the caravan. The Powells engaged him as a servant and he accompanied them all the way to the Atlantic Ocean. The "faithful, willing and efficient" Amoni was left in the charge of a local American missionary who was to find someone with whom he could travel back to Northern Rhodesia. Amoni also received presents: blankets, lanterns, and the remaining supplies plus "enough money to make him a rich man among his own people." He waited at Matadi on the Atlantic coast for about a month and then accompanied a European as far as Lake Tanganyika. On this trip he was less successful for, as he later wrote to Colonel Powell, "my new Bwana forget to pay me." 69

If they did not pick up a new job when the caravan trek was over, servants might seek other avenues, perhaps in the same way as Saidi, gunbearer and capitao of the Colville caravan. Wishing to travel by train from Broken Hill to Livingstone, the Colvilles needed a cook as no food was available during the long train journey. Moffat, their caravan cook, wanted to walk back to Nyasaland together with the rest of the staff, thus leaving the Colvilles in a bind. Then Saidi volunteered, and he proved to be a very good cook. He had "suddenly discovered that he wanted to see the Victoria Falls and that afterwards he would like to earn six months' wages at Bulawayo before returning to Nyasaland."70 At Bulawayo he might have become one of the much praised Nyasa boys. If not returning to Nyasaland, he might have decided he wanted to see Goli (the city of gold), as Johannesburg was known to Africans, for wages increased as workers moved south.

Servants' wishes to see other places and receive higher wages prompted them to leave positions they disliked. Employers constantly complained about the turnover rates, lack of efficiency, and the servants' poor work

68. E. Alexander Powell, The Map That Is Half Unrolled: Equatorial Africa from the Indian Ocean to the Atlantic (New York: Century Company, 1925), p. 7.

69. Ibid., pp. 102-106, 217, 343.

70. Colville, One Thousand Miles, pp. 132, 242. 
habits. ${ }^{71}$ To make Africans work on terms defined by whites, some employers believed in using harsh discipline and instilling work compliance through fear. In his account of life at Livingstone from the end of the last century to about 1919, Percy M. Clark, the town's photographer and its first commercial curio dealer, gives the following advice after describing how he had beaten several houseboys with the sjambok (Afrikaans for whip), which he always kept handy, for giving cheek to their "missus": "I say that a dog and a native are on a par. One should give them a good hiding when they really have earned it, but one should never thrash either until one's temper has cooled. "72

With the arrival of more settlers after the opening decades of colonial rule in Northern Rhodesia, hints, informally observed conventions, and personal idiosyncracies became unsatisfactory as regulative mechanisms. In the new legal framework, inventoried servants became wards of their employers. The laws that guided employment were informed by paternalistic attitudes. The Masters and Servants Ordinance, first implemented in North Western Rhodesia in 1908 and extended over the amalgamated territory in 1912, amended 1913 and 1925, was modeled on legislation in southern Rhodesia and ultimately influenced by South African laws. ${ }^{73}$ It was rationalized by current notions of sanitation and civilization which when taken together saw cultural achievements and capacities as products of distinct racial backgrounds. ${ }^{74}$ Africans were considered to be primitive, raw natives who did not know what was good for them, whereas whites were civilized and responsible for their protection and uplift. As in seventeenth-century England, the term servant meant anyone who worked for an employer for wages, except skilled workmen. ${ }^{75}$ The labor regulations

71. Cairns, Prelude to Imperialism, pp. 31-32, describes these problems as they were experienced by whites who came out between 1840 and 1890, giving examples from their encounter with the Matabele and the Baganda. He suggests that tribal pride in both cases was a barrier to undertaking work for whites. The Matabele could not understand the practice of hiring servants: "they must own them." Unable to recruit Baganda workers, missionaries employed Muslims from the coast, who in turn began spreading Islam among the Baganda and eventually were dismissed.

72. Percy M. Clark, The Autobiography of an Old-Drifter: The Life-Story of Percy M. Clark of Victoria Falls (London: George G. Harrap, 1936), pp. 249-250.

73. Statutory Law of North Eastern Rhodesia, 1908-1911; of North Western Rhodesia, 1910-1911; and of Northern Rhodesia, 1911-1916, and NAZ/NR 3/73. Employment of Natives Ordinance, Amendments.

74. On this, see Philip D. Curtin, "Medical Knowledge and Urban Planning in Tropical Africa," American Historical Review 90 (1985): 594-613.

75. I am aware that this is a controversial statement. See the debate between MacPherson and Lasslett: C. B. MacPherson, "Servants and Labourers in Seventeenth-Century England," in his Democratic Theory: Essays in Retrieval (Oxford: Clarendon Press, 1973), pp. 207-233, and Peter Lasslett, "Market Society and Political Theory," Historical Journal 7 (1964): I50154. 
stipulated among other things that employers house their servants (but not wives and dependents), feed them, and take care of their medical problems.

The stereotype of the good and faithful servant that had developed during caravan travels did not necessarily apply to the relationship between a domestic servant and a resident employer. Misdemeanors had to be dealt with legally, and not in the ad hoc fashion that was characteristic of the traveling caravan. Under the Masters and Servants Ordinance, breaches of contract were considered criminal offenses for which servants were punished with fines or imprisonment with or without hard labor. Breech of contract was an inclusive legal term, encompassing absenteeism, drinking, careless or improper work performance, use of property without permission, damaging of property, refusal to obey commands, insulting language or behavior, and disruptive behavior when in or on the employer's premises. This legislation defined fairly innocuous events as crimes, such as the following 1912 incident concerning public nuisance brought before the magistrate court at Livingstone, involving: "three full-grown natives, two attired in parodies of European clothes, and the third in the white smock and cap of a household servant . . . dancing to the music of . . . a Kaffir piano." In the magistrate's opinion: "they must not create a disturbance in Sackville Street on a Sunday afternoon, the white man's day of rest. These Kaffir pianos are an unmitigated nuisance, and if they want music and dancing they must go into the veld [Afrikaans for bush] and enjoy themselves where they will not cause annoyance."76 They were fined five shillings each or three days' imprisonment with hard labor.

The need for coercive legislation to control the activities of African workers, including servants, bears evidence of an ongoing battle between colonial employers and African migrant workers barely a generation removed from the work rhythms of small-scale cultivation, cattle husbandry, and fishing. In private household service this battle positioned servants and employers in a labor process that involved a new work discipline and new forms of authority, aimed at breaking-in raw natives as workers. It entailed, as noted above, a process of domestication. The employers' constant complaints of inefficiency and laziness may have captured one aspect of this process: their servants' difficulties in adopting, or attempts to resist, new labor regimes that required continuous work rather than seasonally changing or task-determined routines. ${ }^{77}$

76. "Monday Morning at the Police Court," Livingstone Mail, September 21, 1921.

77. E. P. Thompson, "Time, Work Discipline, and Industrial Capitalism," Past and Present 38 (1967): 56-97. 


\section{A Fixture of Colonial Society}

\section{The Institutionalization of Domestic Service}

The knowledge that African menservants acquired from caravan work remained useful even after motor transportation made caravan travel almost superfluous. Some of the porters and men who had specialized as travelers' companions turned to resident domestic service for a living. Former caravan servants and mission boys played important roles in shaping the domestic service patterns their novice resident employers developed. Their employment opportunities increased, for new towns grew up almost overnight in the north, where copper mining was begun on a commercial scale in the late 1920s. The capital was moved from Livingstone to Lusaka in 1935, and all the towns grew tremendously, especially during the World War II years. Many whites were employed in the mining industry, some took up commercial farming, and the Asian population, negligible in size during the first decades of the century, grew and scattered across the country's small towns, where the majority made a living from family-based trade with Africans. ${ }^{78}$ Health conditions had improved, and the malaria danger had lessened, owing to the draining of swamps and the use of better prophylactics. Between 1921 and 1946 the adult white sex ratio became more balanced, so that by 1946 there were 91 white women for every 100 men. ${ }^{79}$ Many more white women joined their civil servant husbands than did previously, although the Colonial Office as late as the post-World War II years discouraged junior officers from bringing out wives during their first tour of office.

The number of African men who did wage labor away from their villages had increased as well. According to Andrew Roberts, by 1936 more than half of the able-bodied male population was working away from home, as many outside the territory as within it. ${ }^{80}$ Linked to the imposition of taxes, the creation of a labor force of this magnitude was part of a rural transformation that by the mid-1930s had undercut the possibilities for peasant agriculture to such an extent that most Africans had become dependent for their livelihood on wage labor. ${ }^{81}$ Between 1928 and 1930 a series of com-

78. The Asian population had grown from 39 in 1911 to 176 in 1939. At the close of the war in 1946, it had shot up to 1,117 according to Report on the Census of Population of Northern Rhodesia Held on the 15th October, 1946 (Lusaka: Government Printer, 1946), p. 9. The Asian population has not been extensively studied. The main work was undertaken in the late 1950s by Floyd and Lillian O. Dotson, The Indian Minority of Zambia, Rhodesia, and Malawi (New Haven: Yale University Press, 1968).

79. Kay, Social Geography, p. 27.

80. Roberts, History of Zambia, p. 191.

81. This is among the chief points made in The Roots of Rural Poverty in Central and Southern Africa, ed. Robin Palmer and Neil Parsons (Berkeley: University of California Press, 1977), pp. 173-174, 291. It has to be qualified by a recognition of the fact that the effects of incipient capitalism and the legal measures used to advance it neither filtered through all rural 
missions had reclassified African lands into reserves located away from areas of white settlement. ${ }^{82}$ Some of these reserves were on unproductive soils and/or were too small to sustain their growing populations. Agricultural quotas discriminated against African cultivators, giving white settler farmers along the line-of-rail preferential access to market their crops. ${ }^{83}$ Using legal measures to condition white privilege, the colonial government at the same time deprived rural Africans from using new productive means other than selling their labor.

African wages were not shaped by the supply and demand of labor but by the colonial government's ideas of the amount needed for subsistence of a single worker rather than of his family. These workers were predominantly men, for working conditions were set up to prevent workers from bringing wives and dependents to town. The lives of African men in the towns were shaped by political, economic, and residential segregation by race and circumscribed by rules and regulations concerning where and with whom they could live and work and how they could move between and within urban and rural areas. ${ }^{84}$ Housing was tied to the job, and once a worker lost his job or finished a work contract, he was supposed to return to his village to join his wife, who in his absence had tended fields and cared for children and the old. Such, at least, was an African worker's career in the administration's view. As I discuss later, not all men workers returned, and not all African women remained in the rural areas. The direction of their movement was temporarily reversed during the Great Depression, when mines and businesses laid off both African and white workers and many Africans did return to their villages. After the depression years, rural to urban migration continued, involving men, women, and children.

Among the local white population, opinions on the desirable course of native administration began to differ, especially after the Colonial Office's publication of the 1930 Passfield Memorandum, which stated the paramountcy of native interets in matters of local policy. Some interpreted the

regions with the same speed nor affected the different population segments in the same fashion.

82. Gann, History of Northern Rhodesia, pp. 136-138, 215-224, 372-373.

83. See, for example, Maud Muntemba, "Thwarted Development: A Case Study of Economic Change in the Kabwe Rural District of Zambia, 1902-1970," in Palmer and Parsons, eds., Roots, pp. 365-395, and Brian Siegel, "The Response of Resentment: The Lamba Vegetable Trade of the Rural Zambian Copperbelt," paper presented at the "Culture, Economy, and Policy in the Colonial Situation" conference held at the University of Minnesota, Minneapolis, 1981.

84. Among these ordinances were the Employment of Natives Ordinance (1929); the Native Registration Ordinance (1929); the Vagrancy Ordinance (1929); the Natives on Private Estates Ordinance (1929); the Township Ordinance (1929); the Municipal Corporations Ordinance (1927); the Public Health Ordinance (1930); and the Native Beer Ordinance (amended 1930). 
memorandum as a blueprint for guided paternalism, whereas others viewed it with horror and held up the Union of South Africa or Southern Rhodesia as models, wishing to see Northern Rhodesia become a "white man's country," perhaps even amalgamated with the south. ${ }^{85}$ Yet in spite of such divergencies in public outlook, and regardless of occupational differences and those of rural or urban location, the colonial residents shared one thing: the employment of African male domestic servants. And of all Africans, only servants were allowed to live in the white parts of town so as to minister to the needs and comforts of their employers.

In structuring their household regimes, white employers drew on two models: the British, where domestic service till the interwar years was the chief urban income source for wage-laboring women, and the South African, where, with the exception of the Cape, African men had dominated in service after the abolition of slavery but were beginning to be replaced by women. Class condescension and racism thus informed servant-keeping practices in Northern Rhodesia and helped to shape the labor relation between black menservants and their white employers.

\section{Employers' Lafestyle}

In bush stations and towns, the presence of more white women helped to develop household arrangements and patterns of lifestyle in familiar ways. A previous generation of white men's approximation of an "African way of life," meaning cohabitation or concubinage with African women, came gradually to be viewed with contempt-though it certainly continued, albeit perhaps more in remote areas and in the manner of casual encounters. Such encounters were best left unmentioned, and against the background of what they held to be strange and uncivilized mores, white householders sought to recreate a world of their own design. Winifred Tapson, a typist for the North Charterland Company and a farmer's wife, noted this quality of the familiar in her description of life at Fort Jameson in the late 1920s: "Here was this relatively large community of white people, men and women and children, pitched into a wilderness of black people and surrounded by a negation of civilized life" (italics added). ${ }^{86}$

85. Legislators had discussed the idea of amalgamation during the $1920 \mathrm{~s}$, and some expressed extreme opposition to the "attrocious suggestions" of the "obnoxious white paper," i.e., the 1930 Passfield Memorandum on native paramountcy as the goal of local colonial activity. Their concerns are highlighted in the Legislative Council Debates and several newspaper articles, from among which the above terms are taken, e.g., Livingstone Mail, January 29,1931 , p. 6 .

86. Winifred Tapson, Old Timer (Cape Town: Howard Timmins, 1957), p. 29. For a historical study of settler behavior with focus on the creation of cultural boundaries between colonizer and colonized, see Dane Kennedy, Islands of White: Settler Society and Culture in Kenya and Southern Rhodesia, 1890-1939 (Durham, N.C.: Duke University Press, 1987). 
This quality of the familiar also struck travelers. When on a motor tour from Johannesburg headed for Nairobi in the late 1920s, Selma Whitehouse and her four companions stopped among other places at Broken Hill, where Mrs. Whitehouse was impressed by the cosmopolitan nature of life. There they met mining engineers from Canada, France, and South Africa: "we have travelled 1500 miles to get here through Darkest Africa, [and] here we came into a colony of people who might live anywhere. . . . [We] have come upon this little community with its country club, and its golf course, and its at-home days!" When the party reached Kasama, her praise continued: "they are all cultured and charming people, and with charming wives they live here in the wilds, keeping house as if in London." 87

The Society certainly had its divisions, for the "boma [administrative headquarters] people and the mine managers [were] the social heads of the place." 88 Below them ranked, according to other writers, missionaries and settler farmers, the latter particularly of Afrikaans-speaking background. European businessmen, often Greeks and Jews, ranked in between them, whereas Asian traders were placed at the bottom. They are hardly ever mentioned in this era's literature, and as non-Europeans, they were probably not viewed as part of The Society. The Afrikaans-speaking farmers tended to be looked down upon. Many of them were poor by white standards, their Calvinist ideology was offensive to some, their harsh treatment of African farm workers left much to be desired, and the lifestyle of many was rough. During her travels in Northern Rhodesia, Eileen Bigland met many "Dutchmen in different walks of life." The year was 1939 and she was not impressed: "Most of them belonged to the genus bully and . . . [held] that judicious ill-treatment was the best way to make an African work hard. They were full of horrific tales of the native customs and habits." 89

In spite of these differences, members of the various segments of the white population shared the same concern with regard to their own households: to recreate a familiar style of living in this remote interior of Darkest Africa. The chief burden of this task fell on white women, who in turn relied on numerous African menservants to carry out most of the actual work. The women who have written about their lives in Northern Rhodesia were clearly supplementary actors in the colonial scheme. Though they were unpaid, the importance of their work should not be overlooked. In the words of Sir Charles Jeffries, the deputy undersecretary of state for the colonies, such women made their contribution by their wifely support, "looking after their [husbands'] health and comfort, keeping house, dis-

87. Whitehouse, Moonlight, pp. 42-43, 57-58.

88. Ibid., p. 46.

89. Eileen Bigland, Pattern in Black and White (London: Lindsay Drummond, 1940), p. 107. 


\section{A Fixture of Colonial Society}

pensing hospitality, enduring when need be separation in order that children may be brought up the way their fathers would wish. "90

But such "incorporated wives," whose ascribed social character was a function of their husbands' occupation and culture, had a role beyond wifehood. ${ }^{91}$ They helped to define the local standards of white civilization. These standards were assumed to set educational examples for African menservants who labored under white women's supervision within colonial households, ${ }^{92}$ and to be of great help to African women. ${ }^{93}$ White women's work, in other words, revolved around day-to-day reproduction of labor, and of social reproduction of a racially divided and class-structured colonial society. ${ }^{94}$

Glimpses of this life may be found in, among others, Emily Bradley's Dearest Priscilla, a book written to advise a fictitious young woman friend on her way to a tropical colony as the wife of a junior official. For it, Mrs. Bradley drew on her own experience as the wife of a colonial civil servant in Northern Rhodesia between 1929 and 1942. Her main role in the colony, Mrs. Bradley told young Priscilla, was to see to it that her husband's creature comforts were supplied at home. With servants to condition their gracious living, married white women in Northern Rhodesia, according to Mrs. Bradley, lived in a man's world where their chief role was that of silent partner. In this scheme of things, the master (Bradley's term) came

90. Sir Charles Jeffries, Partners in Progress: The Men and Women of the Colonial Service (London: George G. Harrap, 1949), pp. 155-156.

91. Hilary Callan and Shirley Ardener, eds., The Incorporated Wife (London: Croom Helm, 1984), p. 1. For colonial African examples of analyses using the concept of the incorporated wife, see Deborah Kirkwood's two chapters on Rhodesia and Beverly Gartrell on Ugan$\mathrm{da}$ in the Callan and Ardener anthology. For a discussion with special focus on Nigeria, see Helen Callaway, Gender, Culture, and Empire: European Women in Colonial Nigeria (Urbana: University of Illinois Press, 1987). For a general discussion of white women's problematic place in the colonies, see Margaret Strobel, "Gender and Race in the Nineteenth- and Twentieth-Century British Empire," in Becoming Visible: Women in European History, ed. Renate Bridenthal, Claudia Koonz, and Susan Stuard, 2d ed. (Boston: Houghton Mifflin, 1987), pp. 375-396. For additional glimpses of the development of white colonial lifestyles in other parts of Africa, see chap. 8, "The DO's Wife and the Governor's Lady," in Charles Allen, Tales from the Dark Continent: Images of British Colonial Africa in the Twentieth Century (London: Futura, 1980), pp. 128-147, which contains a colorful narrative, based on interviews with retired colonial civil servants, only very few of whom lived and worked in Northern Rhodesia. For the British Empire in general and a glorious sentimentalizing recollection about it, see Valerie Packenham, Out in the Noonday Sun: Edwardians in the Tropics (New York: Randon House, 1985).

92. This point was often stressed when officials and legislators discussed domestic service.

93. Jeffries, Partners in Progress, p. 156.

94. Olivia Harris and Kate Young distinguish three aspects of reproduction which affect gender relations in different ways: biological reproduction, reproduction of labor itself, and social reproduction. See their "Engendered Structures: Some Problems in the Analysis of Reproduction," in The Anthropology of Pre-Capitalist Societies, ed. Joel S. Kahn and Joseph R. Llobera (Atlantic Highlands, N.J.: Humanities Press, 1981), pp. 109-147. 
first, as "it was the rule rather than the exception out there . . . that the men can get along without us." 95

A life with many servants offered white women the possibility of leisured living. Once she had given the "morning order" to her servants and decided the meals of the day, a wife could spend the rest of her time on handiwork and reading, painting, and drawing. Some, like Mrs. Bradley, wrote. Many developed fondness for gardening and took pride in growing English flowers in the tropics. The routine was broken by teas and gossip with neighbors and games such as bridge, golf, and tennis in the club. ${ }^{96}$ Some men played soccer and cricket. Rifle clubs existed in many towns and some had ladies' auxiliaries. ${ }^{97}$ Outside of bush stations there was the whirl of white colonial society, consisting of sundowners, cocktail parties, dinner engagements, and dances. ${ }^{98}$

From reading the society columns of colonial newspapers, the external observer might assume that this lifestyle was busy and engaging for an urban colonial wife. Month after month the columns are filled with notices about marriages and braaivleis (Afrikaans for barbeque); holiday dances, club dances, and charity balls; swim galas, cricket, soccer, and fishing competitions; rifle club parties; yearly agricultural shows; Women's Institutes exhibits; and flower shows. These notices show how spaces of the wilds had become domesticated into small islands on which whites sought to recreate the sense of "keeping house like in London."

The white colonists, observed Dorothea Irwin, a newly arrived American woman on the copperbelt in the late 1920s, "were very long on ritual

95. Emily Bradley, Dearest Priscilla: Letters to the Wife of a Colonial Civil Servant (London: Max Parrish, 1950), pp.112, 168-169. After their stay in Northern Rhodesia, the Bradleys worked in the colonial service in the Falkland Islands and the Gold Coast. Kenneth Bradley was a prolific writer and published, among others, The Diary of a District Officer (London: MacMillan, 1943), describing a district officer's life during 1938 at Fort Jameson, and Once a District Officer (New York: St. Martin's Press, 1966), a lively description of his wide experience in the colonial service. Emily Bradley likely modeled her work on the already existing narrative genres of women travelers and new settlers who published their experiences in the form of letters, diaries, and guidebooks. For two early works of this genre, written before the end of the last century by white women whose travels in Nyasaland took them across the extreme boundary regions of North Eastern Rhodesia, see Jane F. Moir, A Lady's Letters from Central Africa (Glasgow: James Maclehose and Sons, 1881), and Helen Caddick, A White Woman in Central Africa (London: T. Fisher Unwin, 1900). For analyses of white women's travel writing during the closing years of Queen Victoria's reign, see Catherine Barnes Stevenson, Victorian Women Travel Writers in Africa (Boston: Twayne Publishers, 1982), and Katherine Frank, who comments among others on Helen Caddick, "Voyages Out: Nineteenth-Century Women Travellers in Africa," in Gender, Ideology, and Action: Historical Perspectives on Women's Public Lives, ed. Janet Sharistanian (New York: Greenwood Press, 1986), pp. 67-94.

96. Bradley, Dearest Priscilla, pp. 84-110.

97. Tapson, Old Timer, pp. 43-46.

98. Bradley, Dearest Priscilla, pp. 84-110. 


\section{A Fixture of Colonial Society}

and precedence, calling, entertainment, etc., in strict order of rank." Their life did have its satisfactions, as noted in her letters home. As wife of the general manager of Roan Antelope at Luanshya from 1928 to 1933, the chief mine then in Northern Rhodesia, she experienced the pleasures as well as the hard work of an incorporated wife. In January 1933 the Irwins hosted Governor and Mrs. Ronald Storrs, who were well known for their fastidiousness on proper observances. She and her servants had spent several days preparing for a dinner party for sixteen guests in a new house built and furnished to the Irwins' specifications. The party appears to have been a success save for "my boys [who] went entirely mad with excitement and ceased functioning completely! . . Towards the end of [the] many courses the boys cracked under the strain, and weird things happened thick and fast. Glasses that should have been put on were snatched away, one course was forgotten completely." Yet Mrs. Irwin's satisfaction and pride is evident: "It was really a job of work, that dinner. I figured that to serve the wines in proper order took 112 glasses. . . The table did look lovely, ... long and narrow, with lace, low bowls of roses, and dull blue candles. The whole home came in for much admiration-they said they had heard in Livingstone that it was the most charming house in the Rhodesias, and they thoroughly agreed." 99

White colonial life developed its own conventions of dress; social hierarchies of who could be invited with whom and seated next to whom; and codes for calling and leaving cards. The custom of calling survived in the colonies after it had faded away in England. It meant that newcomers called on seniors while equals and juniors called on the newcomer. Callers left cards or signed a visitors' book, perferably without being seen. Invitations would rarely be issued until after such calls had been made. Remembering this custom in Livingstone in 1930, Vernon Brelsford, then a newly arrived junior official, commented: "it was said that a bachelor in Livingstone who 'played his cards with skill' could drink or dine out almost every night." 100

The observation of such practices not only reinforced relative rank in the colonial hierarchy but also established a "them and us" difference between whites and blacks. Conventions and order helped minimize outward contacts, made whites appear even more civilized, and lessened the chance for standards to drop. Some people functioned happily in this setting, whereas others felt it dulled their personal initiatives. Gore-Brown for one, himself a member of lower British nobility, preferred his remote estate in the

99. Dorothea Irwin, Far Away and Long Ago (privately published, n.d.), p. 68, pp. 106 107.

100. "Northern Rhodesia in the 1930s," bibliographical notes by Vernon Brelsford, ed. and intro. Dick Hobson (London: unpublished manuscript, 1985). 
Bemba bush to the artificial standards of white settled life in the towns. His remarks, especially on white women, after a visit to the small town of Kasama in the late 1920s starkly contrast with those of Selma Whitehouse, referred to previously. "How glad," he wrote, "one is not to live here. Eight households, not necessarily very congenial to each other, having to do everything, everyday, together - the men do a little mild office work . . . the women I suppose order dinner. They don't garden because there is no water . . . and they don't read (there was a library once, but white ants are eating the books). They play golf, and they plan tennis, and they sit in each other's houses \& talk about 1) each other, 2) the badness of a) native servants, b) the government, 3 ) the roads. They aren't vicious, and they are extraordinarily kind, but oh my word they are dull and they are aimless."101

If white women disliked domestic arts and found parties and conversations boring, they had a hard time. The lot of the wife of a colonial official was not every woman's cup of tea. This according to Charles Jeffries, who noted that "the Appointments Departments of the Colonial Office have sometimes been heard to express the wish that they could select officers' wives as well as the officers." 102 A dislike of the scene, coupled with the many of difficulties they encountered when enjoying what compared to African lifestyles must have been high society, prompted some white women to leave. Some marriages went on the rocks, ${ }^{103}$ and some women developed "nerves." Those who accommodated faced isolation from relatives and friends and, often, separation from their children if they made the hard choice of sending them to boarding schools. The compulsive attention paid to housekeeping and servant management and to the problems experienced in the process was perhaps one important way of passing time.

\section{The Importance of Good Housekeeping}

For the running of a proper colonial home, wrote Emily Bradley to her fictitious young friend Priscilla, a white woman needed to be surrounded by a retinue of specialized boys in the house and on the grounds. When the Bradleys established their first household at Fort Jameson in the late

101. Quoted in Rotberg, Black Heart, pp. 159-160.

102. Jeffries, Partners in Progress, p. 156.

103. A member of the adult female postwar generation, Barbara Carr, who divorced her husband and left for South Africa, discusses several of these problems in two books that display an intense dislike of the local African scene. She grew up as the daughter of a colonial official in Nyasaland, went to school in England, and returned to supervise her widowed father's household before marrying and moving to Northern Rhodesia. Her few positive comments concern Mateyo, a Ngoni servant from Nyasaland her parents had had for fifteen years, who went with her to Northern Rhodesia. He was "the only real buffer between me and my savage surroundings!" Not for Me the Wilds (Cape Town: Howard Timmis, 1963), p. 59, and Cherries on My Plate (Cape Town: Howard Timmis, 1965). 


\section{A Fixture of Colonial Society}

1920s, they employed nine servants: a cook and a houseboy each with a piccanin helper. Around the house, to tidy the grounds, fetch water and wood, five other men were employed. ${ }^{104}$ From the point of view of the employer, the servants formed a hierarchy of domains: kitchen, house, and grounds. Winifred Tapson also had nine servants in Fort Jameson in the late 1920s. They formed a strict division of labor with the kitchen at the top where the cook reigned, absolutely. Next to him in location, though not in status, was his factotum, a diminutive piccanin. He was the cook's right hand, his ten fingers, his legs and his arms. Called the sukumpika or sukumbula in the literature, he was the washer of pots and pans and the link between the cook's domain and the house and the grounds. Within the house, the head houseboy guarded the dona's keys and possessions. Next came the tableboy who waited on table, the bedroom boy who brought the morning tea and folded back the mosquito net, and the bath boy who carried the tin bath in from the outside, filled it with heated water and tempered the temperature before announcing in front of the bedroom door that the bath was ready. On the fringes of this hierarchy floated the dregs of the household, the washboy, the wood boy, and the water boy, whose task it was to provide a never ending supply of those basic necessities. ${ }^{105}$

With so many hired hands, colonial households might seem to have functioned smoothly and white women householders enjoyed unbounded leisure. This is not how many women viewed it. When establishing her new home in Northern Rhodesia, Dorothea Irwin was dismayed by her servants' inefficiency. As she wrote in her first letter to relatives in the United States, she was struck by their numbers but also frustrated. The mining town, which was then opening up, was "growing very fast in population-about 500 to 600 whites, and Lord knows how many blacks. 400 black domestic servants, imagine! But every [white] carpenter's assistant keeps two or three servants. You never saw anything like it. And what ridiculous objects they are! If I could sweep all of mine out and have one good woman worker, I could do in a day what I have not been able to do in a week."106

Quite specific household management advice is provided in Emily Bradley's 1939 Household Book for Africa, again based on her experience in Northern Rhodesia. This book was written especially for the bachelor "faced with the bewildering problem of housekeeping" before the days when British wives commonly accompanied their civil servant husbands out to Africa. ${ }^{107}$ The writing of this book had been suggested to Mrs.

104. Bradley, Dearest Priscilla, p. 58.

105. Tapson, Old Timer, pp. 47-54.

106. Irwin, Far Away, p. 68.

107. Emily Bradley, A Household Book for Africa (London: Oxford University Press, 1939). 
Bradley by Ralph Furse, long-time recruiting officer for the Colonial Service, who on a 1935/36 tour of Africa made a stop at the Bradleys in Mumbwa. So impressed was Furse by "the heart of a lettuce in the midst of a desert" that he there and then talked her into the project. $108 \mathrm{Mrs}$. Bradley must have been well-known locally for her skills in household management. In 1938 she was detailed to assist a junior officer just arrived at Lusaka in buying supplies to bring to the rural outpost at Isoka. It included everything from a full case of whiskey and 150 pounds of flour to a bottle of capers. ${ }^{109}$

The second edition of Mrs. Bradley's book, titled A Household Book for Tropical Colonies, was published in 1948. She aimed it "also to the wives, especially beginners who are equally worried by housekeeping and the bachelor girls who have both homes and jobs to look after." 110 In it, she described the work routine in a colonial household, beginning with the morning order given to cook and houseboy as they appeared with their trays when their mistress opened the storeroom. The cook's tray would have on it tins with lids for coffee, tea, porridge, and salt and cups and basins for the dishing out of food for the day. The houseboy's tray had a sugar basin, a cruet, and a marmalade jar. The containers on each tray were then filled daily according to the menu decided on. This practice, according to Bradley, "saves endless anxiety over the unwonted disappearance of food." 111

She also described the duties of a good cook. He might need quite a bit of coaching till the mistress could trust him to do things as she liked them done, without constant reminding and correction:

1. He must: (a) keep the kitchen scrubbed and the towels and oven cloths washed daily.

(b) Boil the drinking water thoroughly in a clean kettle and pour it into sacks to cool, one each night. Sacks should be washed out frequently with coarse salt, cold water, and a few crystals of potassium permanganate.

(c) Boil the milk, keeping saucepan, cooling basins and straining muslin spotless.

(d) Keep his tins for tea, coffee, crumbs, fat, salt, etc., clean and covered. He must not store his own treasures among the food.

(e) Keep his apron clean. Don't employ a boy who is not clean. Good boys are

108. Ralph Furse, Aucuparius: Recollections of a Recruiting Officer (London: Oxford University Press, 1962), p. 253, in which Furse also told that Emily Bradley was an American. Furse misidentifies the book in question, referring to Dearest Priscilla and not A Household Book.

109. Rhodes House. MSS Afr. s. 664. J. C. Walter papers.

110. Emily Bradley, A Household Book for Tropical Colonies (London: Oxford University Press, 1948), p. vii.

111. Ibid., pp. 16-18. 
African cook. Photograph from the reprint of the Northern Rhodesian Handbook (Lusaka: Government Printer, 1953), p. 94. Original photograph probably from the 1940s.
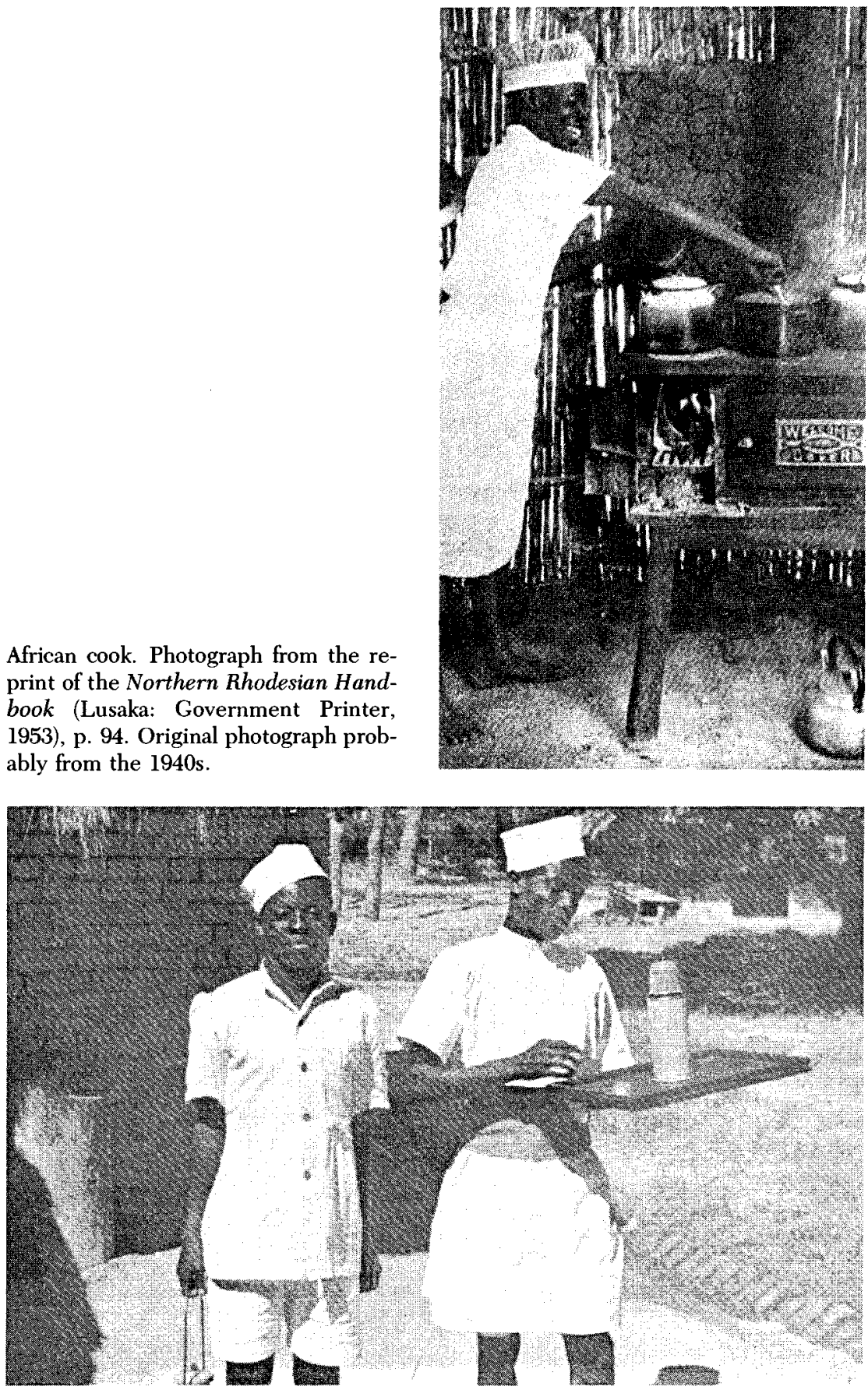

Michek and Kosam at Kawamba, 1947. From the collection of Mary and Reginald Thompson. Reproduced with permission. 
most fastidious about their hands. A persistently oderous boy must be dismissed if he does not respond to frequent baths with carbolic soap.

2. A good cook should be able to make bread, soup stock and good white sauce at least; to cook vegetables carefully (not soggy over-cooked potatoes and cabbage!); to roast meat so that it is brown on the outside, soft and juicy on the inside, and not greasy; to understand the method of making:

(a) Cake: i.e., cream butter and sugar.

(b) Scones and pastry: i.e., rub fat into flour.

(c) Batter: i.e., make a hole in the flour.

(d) Brown soups and sauces: i.e., fry onion in fat.

(e) White soups and sauces: i.e., melt butter, add flour, etc.; boil onion in milk.

He should also be able to devise a variety of breakfasts, and make good coffee and tea.

Concluding her description, Emily Bradley suggests that a boy who understands two-thirds of the above should be taken on gratefully and the mistress then set about bringing the other third up to standard.112

The number of servants employed depended on locality, that is, rural versus urban, and on the amenities present. Toward the end of the Bradleys' stay in Northern Rhodesia, the number of servants in their household had declined to five. They then lived in Lusaka, their two sons were away at boarding school, and they had at that point the benefit of such technological improvements as piped hot and cold water, flush toilet, and fuel delivery. ${ }^{113}$ They probably also had electricity and refrigeration.

In addition to locality and the sort of amenities present, the employment of specialized servants also depended on the composition of the employing household. With the birth of children, new needs arose. The real need at this stage of the family's development cycle, according to Mrs. Bradley, was "that of an attendant." Since she herself had no daughters, it was never necessary to employ another woman, white or black, to help with childcare. All she had was a "nurse-boy to push the pram and wash the nappies." But from friends who had white nannies she understood there were many snags: "All the problems of leisure and pleasure applied to them as well as the mistress. There was no opportunity for them to have any sort of social life on their own apart from their employers. They were part of the family, belonged to the club, and Mother and Nanny took turns about playing games, or attending club dances. African [male] servants made difficulties of discipline over another white woman in the house whose position they didn't quite understand." Properly trained children's nurses were almost nonexistent in Africa, she told Priscilla. "Anthropologically or sociologically

112. Ibid., pp. 19-20.

113. Bradley, Dearest Priscilla, p. 59; following quotes, pp. 230, 58, 230-231, and 231233. 


\section{A Fixture of Colonial Society}

speaking," she continued, "a young African woman of good family does not take up children's nursing. . . . Her life is governed by her family from cradle to altar, within rigid tribal codes, and a few years of independence between her parents' home and her husband's is as unthinkable to them as it was in our own society not so long ago." That it was almost unthinkable for whites in Northern Rhodesia to employ African women in domestic service is corroborated by the numerical record on servant employment. 114 Emily Bradley's remarks on how to manage a colonial household help us to understand why, but perhaps, as I suggest later, there were reasons other than those she gave.

The men who worked as domestics were often recruited upon the recommendation of neighbors or colleagues or of a trusted African worker on the staff of the household or of the husband's place of employment. They were sometimes the "brothers" or friends of already known African workers. Others "came with the house" and worked for its new residents. As mentioned earlier, some white women did prefer raw natives fresh from the bush whom they could domesticate themselves. But in general, workers with traceable work records were preferred. When presenting themselves, servants looking for work carried reference books. These were checked for length of employment, with what sort of people, and the hopefiul servant was asked if he drank. ${ }^{115}$ In her advice on hiring, Emily Bradley never mentioned the need to ask questions about the servant's personal background, his marital status, or ethnicity.

The available statistics tell little about the servants' ethnic backgrounds. Employers continued to consider Nyasa boys, meaning men from the border regions of Northern Rhodesia and Nyasaland, among the best, as well as very congenial workers. If indeed domestic service was characterized by an ethnic division of labor in which men from that region dominated, it is likely to reflect the poor conditions in peasant agriculture and the lack of rural employment alternatives. ${ }^{116}$ Large numbers of migrants did come from the Eastern Province, where there were land shortages after the allotment of reserves and where wage labor on tobacco farms had shrunk after the 1938 slump in the tobacco market. Some of these men may have made their way into service, but just how many is uncertain.

Employment was usually first on a trial basis to ensure that the two parties could get along. After a while the woman householder would, according to Bradley, "doubtless discover whether Cook is amenable to instructions and likes learning new things, and whether or not the houseboy

114. See Tables 5 and 6 for numbers employed in domestic service categorized by sex.

115. Bradley, Dearest Priscilla, p. 53.

116. H. Leroi Vail, "Ecology and History: The Example of Eastern Zambia," Journal of Southern African Studies 2 (1977): 129-155. 
has been working on the theory that what the master doesn't see won't worry him." 117 If the servant's behavior was tolerable, a monthly contract would be made, with wages paid weekly, fortnightly, or, more commonly, once a month. Food or ration money, sometimes referred to as posho, was also provided, as were occasional castoffs such as clothing from the employing household. Emily Bradley recommended giving servants a day off each week and one Sunday in three, or even occasional weekends, especially if the servant's wife and children did not live with him on the premises. A two-week holiday with pay once a year or every two years, particularly if the servant's village was far away, might be part of the contract. 118 Rates of pay, time required at work, and holidays all depended on arrangements between employer and servant since no formal regulations were established.

\section{Space and Place in the Colonial Household}

The almost compulsive attention to the do's and don'ts of housekeeping conveyed in Emily Bradley's recommendations may reflect an unconscious attempt to control a situation ripe with contradictions. The racial stratification of colonial society was supported in part by mechanisms for maintaining distance. ${ }^{119}$ These mechanisms were both social, prescribing etiquette and comportment, and spatial, requiring segregation. Servants were in these white households, but never of them. The physical proximity of servants and employers belied the chasm between them which the racial and economic premises of colonial society created.

The Masters and Servants Ordinance and its later amendments stipulated among other things that employers should house their servants. Cooks and houseboys were often accommodated in servants' quarters, known by the Portuguese term kaya, in their employers' backyards. The hierarchical relationship between master and servant was manifested in the layout of the grounds with the servants' quarters built alongside the sanitary lanes from which nightsoil, in the days before flush toilets, and garbage were collected. Where such housing was unavailable, or when employers did not want them to reside on the premises, servants received an allowance and had to find shelter in the African parts of town, commonly referred to as compounds, or if at an outstation, in a nearby village. To facilitate their coming and going, especially their late-night return after

117. Bradley, Dearest Priscilla, p. 47.

118. Ibid., pp. 59, 65.

119. See Pierre L. van den Berghe, "Distance Mechanisms of Stratification," in Readings in Race and Ethnic Relations, ed. Anthony H. Richmond (Oxford: Pergamon Press, 1972), pp. 210-219. 


\section{A Fixture of Colonial Society}

evening chores since a 9 P.M. curfew prohibited Africans' moving about in the white parts of town, employers wrote "night passes" for their nondomiciled domestics.

A properly managed colonial household was part of civilized society and as such it was on permanent display. ${ }^{120}$ The labor behind the display was done by numerous African servants who from the perspective of their employers were members of an otherwise formless African mass and somehow had to be socialized into work on white terms. To differentiate them from other Africans, servants not only were housed on the periphery of their employers' premises and given special passes to enter white areas; they were also set off from other Africans by their manner of dress. Houseservants were supplied with at least two complete uniforms, usually a khaki tunic and trousers for day wear, the equivalent in white for the evening, small hats or fezzes, "plus aprons for cook, and soap all round."

The display and upkeep of white civilized standards required work efficiency. To promote it, madams observed the hierarchical division of labor among house, kitchen, and grounds and the elaborate rules of etiquette which governed conduct. These rules and conventions served both to set servants off from other workers and to mark the social distance between them and their employers within the household. White women were advised to "talk slowly, simply, and distinctly" when speaking to servants in English and to treat them with "tolerance and understanding, but not with familiarity. Discipline should be firm, but fair."121 The paternalistic tone is clear: servants were considered children.

Generically, and regardless of age, all servants were referred to as boys, as were, for that matter, all other African men save perhaps chiefs and headmen. Servants were rarely addressed by their own names. Many white employers would garble a cook's or houseboy's African name into something more manageable for the Anglo-Saxon tongue. Some became known under biblical names such as Amos, Elijah, Isaac, and Moses. Others were called Sixpence, and Pumpkin, Wireless, Bicycle, Cigarette, or

120. The distinction between domestic or private versus public sphere becomes relative in this situation and is perhaps related more to an ideology of power and control than to differential involvement across space. This distinction was elaborated especially by Michelle $\mathrm{Z}$. Rosaldo, who suggested that women's status in various societies was influenced by the degree of differentiation between the two domains: "Women, Culture, and Society: A Theoretical Overview," in Woman, Culture, and Society, eds. Michelle Z. Rosaldo and Louise Lamphere (Stanford: Stanford University Press, 1974), pp. 17-42. This distinction has since been viewed as simplistic and of doubtful historical and cross-cultural value. For more on the relativity of space and its social and ideological partitioning, see Shirley Ardener, ed., Women and Space: Ground Rules and Social Maps (New York: St. Martin's Press, 1981); and Callan and Ardener, Incorporated Wife.

121. Northern Rhodesia Information Department, Northern Rhodesia Handbook (n.d. Lusaka: Government Printer, 1950; reprint of an earlier version, n.d.), p. 78. 
Cabbage. The servants on their part did not always know the exact names of their employers, who were referred to and addressed as bwana or master, or missus, dona, or madam.

Servants rarely wore shoes when in the house. They were not to rest in chairs or sofas, read newspapers, listen to the radio or play the radiogram in either the employer's presence or absence. Servants were not to use the facilities of the main house. Some areas were off-limits to prevent pilfering: kitchen stores and liquor cabinets. Africans in general were by law forbidden till the late 1940s to buy and use "European liquor." 122 In many households it was locked up and guests might help themselves "as the boys do not even handle it." 123 But bedrooms seem not to have considered private space. Most white colonists had morning tea brought to the bedside and boys made their beds and washed their sheets.

When on duty, servants were not supposed to talk unless they were spoken to. Communication around domestic work was itself a hierarchical situation, especially in households where "Kitchen Kaffir" was the main communicative mode. ${ }^{124}$ This hybrid language, which had arisen through contact between whites and blacks in South Africa, was used to some extent in Northern Rhodesia, especially by settlers who came up from the south, but it never developed into a lingua franca. Consisting mainly of command and obey expressions, Kitchen Kaffir provided a language of subordination. Unlike in India, where white women were encouraged to learn the local languages and English-speaking servants were distrusted, their sisters in Northern Rhodesia went to no great lengths to learn any of the local languages. ${ }^{125}$ While employees of the provincial administration, the police,

122. When European wines and beers had been made available to Africans, a group of white women wrote an indignant letter to the editor. They referred to weekend domestic disruptions due to their servants' indulgence in "Kaffir beer," i.e., commercially brewed beer meant for African consumption. Yet Kaffir beer was checked for its alcohol content, they noted, so why introduce Africans to more? "Kaffir beer brewed and sold under observation may be good for the African, and it is natural for him to drink it. . . Why introduce him to another of our vices?" Letters to the Editor, "Housewives Concern," by "The Group," Central African Post, October 13, 1948, p. 3. But an African man responded that "legislators knew that there was no harm in allowing wines and beers to Africans, because it won't make him worse. I would agree, if gin and other things were allowed to him. . . . European liquor which has been allowed to be purchased by the Africans is $20 \%$ weaker than the present beer brewed by Africans" (i.e., illegal, home-brewed beer and distilled alcohol, and not the Kaffir beer sold in the municipal beerhalls). He concluded: "I think time is coming when a housewife shall have to face the houseduties when the men African servants will demand more pay. What will happen then?" Letters to the Editor, "Housewives and Africans," by "One of Those Africans," Central African Post, October 28, 1948, p. 3.

123. Bradley, Dearest Priscilla, p. 60.

124. Kitchen Kaffir, Chilapalapa, or Fanagolo is a hybrid language consisting of elements from Zulu, English, and Afrikaans.

125. Charles Allen, ed., Plain Tales from The Raj: Images of British India in the Twentieth Century (London: Futura, 1976), p. 90. 


\section{A Fixture of Colonial Society}

and the army were required before advancement to pass examinations in one or more of the major African languages spoken in the territory, other officials, including professional magistrates and the judiciary, were not and used African interpreters. ${ }^{126}$ Some of their wives picked up an elementary vocabulary of a local language, especially if they lived for several years within the same language area. Since most colonial officials were transferred across regions frequently, the opportunity to absorb a local language was limited. Many servants learned household English on the job, while others had acquired a rudimentary knowledge of that language in schools. Servants who did not master English well were likely to be caught in all kinds of problems: mixing the wrong ingredients into recipes, not doing what they were told to do, or doing it very differently.

The linguistic problems arose because Bantu languages express pronouns and negations in different ways from English. Imagine the domestic strife that may have been caused by the servant's wrong use of gender when describing his madam's unexpected visitor to his returning master. Such mistakes, as well as their inconsistent use of English pronouns and the negative affirmative were the stuff that servant stories were made of. Exchanged at women's teas, such stories helped consolidate the image of the servant as inferior to his madam and accentuated the distance between the two in the otherwise shared space of the household. Not necessarily malevolent, such stories construe servants as inherently irresponsible, having no sense of time, lazy, lacking understanding, and therefore in need of constant supervision and coaching. Mary Thompson provided, among others, "a true story of a bachelor, a farmer who liked to read over his solitary meal and his servant would put a book by his plate. One evening he did a rare bit of entertaining and each guest found a book placed neatly before him at the dinner table."127

The etiquette of dress was also of great concern. Revealing clothing should not be worn in the presence of servants. Some colonials dressed in evening garb for dinner at home. At formal events, hats, gloves, and pumps were de rigeur for women. While such dressing habits might reflect those current in European bourgeois circles at the time, they did not necessarily express what was practical in the tropics. Even cinema visits required dinner jackets and robes if a high-standing colonial official was present. Stories were told, humorously, of officials traveling on up-country tours and dressing formally for their camp dinner in the bush. But "keeping up appearances" and "dressing for dinner" in the heart of the bush were not fiction. According to W. V. Brelsford, "many of these lonely bachelors

126. Roy Stokes, personal communication, December 18, 1983.

127. Mary Thompson, personal communication, August 24, 1982. 
believed such habits were essential for the maintenance of morale." 128 The humor that accompanied such stories does not convey what the concern for proper appearance achieved: a reassuring of the familiar, the maintenance of civilized standards, and an ideological legitimation of difference between white and black and of white domination over black.

If they dressed "like Europeans," Africans challenged the function of dress to mark social difference, and whites reacted with predictable hostility. White travelers during the early decades of this century treated with condescension servants' attempts to dress up "like them," and the antagonism did not abate with time. In a 1949 newspaper article advocating racial segregation, the writer of "Some Illusions of the Bantu" noted that although the African could live comfortably on much less than whites, "he wants to wear boots and hats and European clothing-which are unhealthy and unsuitable-, and his wife wants to wear dresses, silk stockings and highheeled shoes and hats—also unsuitable and unbecoming." Even when they step out of place and into whites' clothing, this writer concluded, "they will never be anything but poor imitations of the higher race." 129

The colonial household was built on contradictions of space and place which involved both servants and their employers. It was the employer's territory, but because it was on permanent display, the household was hardly a private domain. It was open to other whites for inspection. And to the servants, it was a very public place: it was their work locus and they knew every nook and cranny as well as what went on inside. In some instances, it also enclosed their home, and then not only space but also time was public. Servants domiciled on the premises were on constant call; even if their work chores were done, they were still considered available. Ironically, the result was the same for both servant and employer: the private domain was one of time, and it existed primarily when servants were off duty and not called on.

All aspects of life were regulated for the domiciled servants: whether or not to live in, when and which visitors could call, what sort of activity might be undertaken in leisure time. In fact, this unequal incorporation into the household was something they shared with their madams. White women in the colony did not hold a particularly strong position. They were prisoners of the ideology that associated women's place in the home with the upkeep of civilized standards and supported inequality between women and men.

128. W. V. Brelsford, Generations of Men: The European Pioneers of Northern Rhodesia (Lusaka: Government Printer, 1964), p. 120.

129. "Some Illusions of the Bantu," Central African Post, October 27, 1949, p. 5. The writer suggested racial segregation as the solution to the problems. He recommended that readers consult a notably racist and segregationist book written by a white South African, $\mathbf{H}$. R. Abercrombie, Africa's Peril (London: Simpkin Marschall, 1938). 
Being wives of men in power, their status derived from their husbands' occupations and their personal lives merged into officialdom just as servants' personal lives to a large degree were subsumed by their employers. White women's willingness to play charming and delightful wives for their husbands was conditioned by an acceptance of the colonial hierarchy in its racial and patriarchal dimensions. ${ }^{130}$

Most white women had but one domain in which to exercise personal power: in their own homes over their menservants. Housekeeping may have had its satisfactions, for it allowed women to run their homes and boss servants. Their charge to hire and fire servants gave them at least a taste of power. Perhaps the difference between white men's relaxed attitude and white women's tough attitude to servants must be seen in this light. White women's disciplinary stand was both a shield to protect themselves as employers against workers and a means to exercise some authority without overtly challenging the inequality in their relationship to their husbands.

In this situation, race and sex impinged in complex ways on what was fundamentally a class relationship between employer and servant. This relationship became charged because of the spatial proximity of the white madam and her black manservant. The convergence of race, class, and sex within the tight space of the colonial household made it difficult for the two chief actors to remain unaffected by the opposite sex.

The rules and regulations, etiquette and decorum that developed in colonial household employment accentuated the social difference between servant and boss but did not disguise that one was a man and the other a woman. How did white women and African men react to this? African men's work in colonial households gave them intimate knowledge of white habits, for servants washed and ironed every item of their employers clothing and made the beds. They also, of course, saw their employers' misconduct and possible indiscretions.

White women in Northern Rhodesia are likely to have viewed their African men domestics first as members of the inferior race, different from whites, less capable, more like children, and only secondarily as male and thus sexually threatening. Undoubtedly, sexual phobias were bandied around at white women's teas as were stories told in beerhalls of African servants seducing their white madams, whether true or false. But the collective sexual hysteria that swept South Africa between 1890 and 1914 did not occur in Northern Rhodesia. Very few "black peril" cases were recorded there. Mrs. Bradley reasoned that "it is a hard fact of sociological

130. For an insightful discussion of a variation of this situation, see Jane Hunter's work on American women missionaries in China in the early 1900s, The Gospel of Gentility (New Haven: Yale University Press, 1984), esp. pp. 128-173. 
statistics that 'black peril' is only rife in more civilized places where white people have lost or thrown away the respect of the colonized races." 131 Of how menservants viewed their white madams little is known. They are as likely to have told stories of their madams as the latter did of them. They probably saw them as whites first, members of a privileged class who wielded power over them. White women were, after all, the bosses who could hire and fire and report any misdemeanors such as drinking, pilfering, and misuse of property. Menservants' inferior status may have muted the sense of troublesome sexuality which lay beneath the surface of the social practices that structured their relationship with white women employers.

Whatever ties of affection developed between servant and employerfor of course there were kind and generous employers and obliging and faithful servants-their relationship was inherently hierarchical and characterized by domination and subservience. The inequality was accentuated in clothing, speech and demeanor. The use of a classificatory label rather than a name rendered the African's personal circumstances irrelevant to the work situation. The wearing of uniforms and the nonuse of shoes when inside set the servant off from both employer and fellow Africans. The Kitchen Kaffir spoken in some households crudely exemplified a language of subordination. The demeanor of not talking unless spoken to, of being present without being seen, reduced the person to an object. These were the official points of contact between the servant world and that of their employers. Taken together, such social practices construed the servant as different from, other than, his employers.

By the interwar period when the sex ratio of whites had balanced, domestic service had developed from a set of common practices originating in the days of caravan travel and mission stations into a taken-for-granted world of unequal relations and routines. This occupational domain had, in Giddens's terms, become institutionalized. ${ }^{132}$ One result of this process was the construction of gender in domestic service as male. Further, it meant the establishment of practices and rules that helped to lessen two inherent contradictions in domestic service: the shared space of the dominant and the subordinate within the white colonial household; and the sexual confrontation between the African male servant and his white female boss.

The construction of the male servant's role as an object or commodity, almost a nonperson, may - in the terms of Mary Douglas and Victor Turner-locate him in a social and cultural limbo at a structural margin, marked

131. Bradley, Dearest Priscilla, p. 56.

132. Anthony Giddens, Central Problems in Social Theory (Berkeley: University of California Press, 1979), p. 80. 


\section{A Fixture of Colonial Society}

off from the mainstream of society. ${ }^{133}$ The servant's ambiguous role seems also to fall within the analytical domain of the drama of face-to-face interaction, captured so sensitively in Erving Goffman's work. Thus at one level of analysis, the colonial household may be viewed as a total institution ${ }^{134}$ in which recurrent features of social interaction can be observed at close range. In such a situation the reciprocal stereotyping and the presentation of selves ${ }^{135}$ in tactics of subservience and domination ${ }^{136}$ can be studied in a regime where, as Goffman puts it: "two different social and cultural worlds develop, jogging alongside each other with points of official contact but with little mutual penetration." 137

Yet, the colonial household was not marked off from the rest of society and it was only in a limited analytical sense a total institution. That limited sense is confined by the terms used by the dominating group to differentiate servants from themselves and other Africans. Their discourse applies to an atemporal, repetitive everyday routine within the closed space of the colonial household and, as I demonstrate at length in Chapter 3, ignores the effects that servants' activities beyond the work locus had on the organization of household work.

\section{Servant Problems: Questions of Control and Regulation}

African menservants were part of white colonial households in the manner of pots and pans. As household commodities, they were the subject of much discussion: ways of handling them, their price and work capacity. If servant stories were frequent conversation topics at women's teas, so were discussions of servant problems, chief among which were complaints about their lack of hygiene, poor work efficiency, insubordination, pilfering, and high turnover rates. These perceived problems were overwhelmingly attributed to servants themselves. Women's second gripe was their husbands' lack of attention to domestic affairs which exacerbated the problems with the servants. Finally, "the government" was criticized for not doing anything to straighten up recalcitrant servants.

Some madams complained that their husbands were oblivious to their

133. Mary Douglas, Purity and Danger: An Analysis of the Concepts of Pollution and Taboo (London: Routledge and Kegan Paul, 1976), pp.115, 145, and Victor W. Turner, The Ritual Process: Structure and Anti-Structure (Ithaca, N.Y.: Cornell University Press, 1969), pp. 102-107.

134. Erving Goffman, Asylums (Garden City, N.Y.: Doubleday Anchor, 1961).

135. Erving Goffman, The Presentation of Self in Everyday Life (Garden City, N.Y.: Doubleday Anchor, 1959).

136. Erving Goffman, "The Nature of Deference and Demeanor," American Anthropologist 58 (1956): 473-502.

137. Goffman, Asylums, p: 9. 
problems with servants. Because he was relatively divorced from the daily execution of household work, a husband might make a request of a servant that contradicted madam's instructions. The confused servant who chose to follow master's orders was likely to be blamed by his missus, especially if he argued. A husband's whims could thus upset established routines, so that noninvolvement might have been the safest approach to domestic matters. Yet husbands were not always allowed to remain neutral; they were called on when things got out of hand and if authoritarian decisions needed to be made. In the domestic power struggle, however, they were not always immediate allies. A wife, when she complained of getting "yards of cheek" from a servant might, as one of them satirized on a newspaper woman's page, get the following unsympathetic answer from her husband: "I've always got on well with the boys. It's all a question of knowing how to handle them." This same writer resorted to staging a near nervous breakdown, making her husband's life a misery, before he agreed to sack an offending cook. When taking on her next cook, she realized that he probably had been laid off from his previous job for the very same reasons that she had wanted her former kitchen worker dismissed. And so her story continues, life interrupted by continual servant problems and inaction on her husband's part, until she finds the solution she recommends to her servant-employing sisters: keep out of the kitchen. ${ }^{138}$

There were of course good- and bad-natured servants, well-intentioned and harsh employers; some servants had better skills or were quicker to learn than others; and some madams and masters had long experience as servant employers in colonial settings whereas others were greenhorns. Some women made bad bosses and some servants, themselves heads in their own households, had a tough time taking orders from a woman, white or black. The worst combinations of any of these factors were likely to produce bad results. "Between the two extremes," commented the native commissioner in Livingstone in 1926, "of the man who spoils his servants, allows himself to be robbed by them and keeps so large a staff that little is required in the way of work for any individual member of it and he who regards his single servant merely as a 'nigger' who is to do everything he is told from chopping wood to boiling eggs and making beds, there lies a large range of moderate people who try to treat their servants fairly but require some return in the shape of efficient performance of duties. This class neither prosecutes defaulters nor is it prosecuted as a general rule; it prefers to suffer and avoid court. That it does suffer . . . is too well known." 139

138. From the Woman's Angle, "Too Many Cooks," by E. G. R., Central African Post, May 25, 1950, p. 7 .

139. NAZ/ZA 1/9. Department of Native Affairs. Licensing and Registration of Domestic Servants, 1929. Native Commissioner, Livingstone, to Secretary for Native Affairs, Livingstone, May 13, 1926. 


\section{A Fixture of Colonial Society}

In an attempt to lessen problems, authorities suggested in 1926 the passage of a legal ordinance requiring the registering and licensing of servants. The need for some regulation had been expressed particularly by white residents of Livingstone, then the territory's capital and hub of its Society, and Broken Hill, then its main industrial center. "The trouble is," argued the native commissioner, that we are "permitting the growth of a class, numerous members of which live by preying on the European to an extent unbelievable by anyone who has not had intimate personal experience of the difficulties of employers and employees in relation to each other." 140 The district commissioner from Broken Hill was in accord, and further explained that white employers suffered "at the hands of native domestic servants who invariably give false names when engaged, desert when the inclination takes them, demand wages for uncompleted terms of service ...., and continuously pilfer and consequently many European women detest the sight of a native and believe them to be quite beyond the control of government."141

Time was ripe for some sort of regulation to keep servants in line, to eliminate the "bad hats," and to open the way "for the native who genuinely intends to adopt domestic service as a living and to do his best in his chosen walk of life." 142 When considering what to include under a licensing ordinance, officials consulted domestic service regulations from other colonial territories: a Northern Nigerian proclamation of 1905; licensing rules from Uganda passed in 1924, from the gold Coast of 1924, and from Nyasaland. ${ }^{143}$ Among the most frequent suggestions made by officials for areas to be covered by a licensing ordinance were medical examinations to exclude servants with venereal and infectious diseases; compulsory testing of references in the situpas (servants' passbooks); prohibitions of misuse, copying, and forging of passbooks; and revoking of licenses of servants who were irregular or who deserted. 144 The police sergeant at Livingstone suggested a clause to deny licenses to servants who had committed or attempted to commit rape of white women and girls or who had indecently assaulted or shown curiosity toward them. 145

140. Ibid.

141. Ibid., District Commissioner, Broken Hill, to Secretary for Native Affairs, Livingstone, July $28,1928$.

142. Ibid.

143. Ibid. Gazette copies from various colonial territories are included in this file.

144. Some whites made money from copying and forging certificates in character books. The district commissioners' offices were authorized to write out clean copies of dirty and worn character books. They were to destroy the originals but did not always do so, and some old character books would be passed on or sold to other Africans. "It enables rogues and scoundrels of all descriptions to obtain employment which they would not get without a certificate of character book." Ibid., Sergeant-Major, Police Warrant Officer of Mazabuka to officer in command of town and district police in Livingstone, February 2, 1927.

145. Ibid., Acting Assistant Magistrate, Livingstone, to Secretary for Native Affairs, Livingstone, May 10, 1929. 
As on almost all subsequent occasions when officials considered "doing something about" domestic service, they failed in this instance, for there were many stumbling blocks. Not all the laws of other colonies were relevant or applicable to Northern Rhodesia. A licensing ordinance might in the future have to be extended to areas not administered by current township regulations and thus changes in rules might be required. ${ }^{146}$ The medical establishment was not sufficiently extensive to examine all servants. ${ }^{147}$ The compulsory giving of character references could be used to the disadvantage of servants as "there exists . . . the class of Europeans who out of sheer spite owing to some small grievance gives a native an undeservedly bad character." 148 And if an ordinance were to be inclusive, it would apply also to "Europeans in domestic employment and it seems . . . hardly necessary to license European women who are forced to earn their living as house keepers, lady helps, nurses, etc." 149 Servants in Northern Rhodesia thus were never licensed, and in later years, when the need for legal regulations was brought up, the dismal failure of a licensing scheme in Kenya was generally referred to as setting a bad precedent. Most problems between servants and employers continued to be dealt with interpersonally.

Employers typically attributed their problems to the simplicity or badness of their domestic servants rather than to the work regime in the white household and its emphasis on order and regulation. Because the domestic space was both a site on permanent display of proper civilized standards and at the same time the locus of work for the servant, a white woman's freedom to pursue whims and idiosyncracies was to some extent limited by the servant's presence, by when and where he pursued his household tasks. From this fact might arise the idea of servants controlling their madams' lives which has been so creatively elaborated by such writers as Doris Lessing. ${ }^{150}$ It is true that decorum was felt necessary in the interaction with servants, and in this sense servants' presence influenced their employers' habits. But this is a different matter from servants controlling

146. Ibid., Native Commissioner, Livingstone, to Secretary for Native Affairs, Livingstone, August 23, 1926.

147. Ibid., Native Commissioner, Livingstone, to Secretary for Native Affairs, Livingstone, May 13, 1926.

148. Ibid., May 18, 1926.

149. Ibid., District Commissioner, Broken Hill, to Secretary for Native Affairs, Livingstone, July $28,1926$.

150. This theme is developed, for example, in Doris Lessing's short story "A Home for the Highland Cattle," in Five: Short Novels (London: Michael Joseph, 1953), and in her novel The Grass Is Singing (London: Michael Joseph, 1953). Lessing's setting is Southern Rhodesia. Nadine Gordiner has given this theme political relevance in July's People (New York: Viking Press, 1981), where she suggests a postrevolutionary stage in South Africa in which a white family flees with their servant to his remote village; there the authoritarian, hierarchical relationship that once structured his work in their household is reversed, and he literally assumes control over their lives. 


\section{A Fixture of Colonial Society}

their employers' lives. A servant's desertion or drunkenness certainly inconvenienced the pursuit of an employer's lifestyle, and a mistress obviously felt done for when having lost, say, five servants in one month. But there were many to replace them and she still had de facto control. She could sack the servants whose work habits interfered most with her own likes and dislikes.

That servants occasionally asserted their independence and employers sometimes suffered may imply that some servants attempted to turn the institution of domestic service to their own advantage. The terms that governed servants' work were set by whites, but they could nonetheless be used to challenge the institution (which was not at all as hermetic as the previous discussion might imply). Although their situation was perhaps special, servants were members of their own households and workers among other workers, and these other relationships also affected their work as servants.

\section{Servants and Their Other Lives}

In the late 1920s, when copper mining began on a commercial basis in the north, a large African labor force was hired for the mines, for the ongoing construction work, and as domestic servants for the rapidly growing white population (see Table 1). This massing of Africans required tighter administration. From the end of the 1920s through the early 1930s a series of new rules and ordinances restricted the movements of Africans between rural and urban areas as well as within the towns. ${ }^{151}$

This era's labor legislation consolidated the Masters and Servants Ordinance and its various amendments into the Employment of Natives Ordinance of 1929. The word servant was omitted from its title and the legislation extended to cover every category of African employee, including skilled workmen. It tightened the contract system, making workers liable to criminal punishment if they deserted before completing contracts. Criminal remedies continued to be meted out for misconduct, "because the civil remedy would be ineffective in regard to natives who have little sense of responsibility, usually possess no property, often have no fixed place of abode, and generally are quite indifferent to dismissal." 152 The ordinance also gave the servant "a criminal remedy against his employer for nonpayment of wages. . . . Although some natives have achieved a veneer of education and skill and have by contact with Europeans became in some ways amenable to the ordinary standards of civilized life, even the most

151. See note 84 .

152. Northern Rhodesia. Legislative Council Debates 10 (1929), col. 56. 
advanced of them are still very irresponsible, credulous and gullible and require the protection of the criminal law against many European employers." 153

Paternalism continued to inform labor relations and perhaps supremely within servant-employing households, where some masters thought they eventually would "make over" and civilize their servants. Because servants worked in their employers' space and their behavior was governed by their employers, masters commonly believed that they "knew" their servantsand thus, by extension, all Africans. A stereotype had arisen of servants as "ridiculous objects . . . [yet] rather appealing, too; very gentle and anxious to please, in all their blunders and weird ways." 154 Because of their "simplicity," servants were also considered impressionable, and up till World War II it was generally thought that they would pick up civilized mores under white supervision and apply this knowledge in their own lives. Many whites thought that there was "hope" for the domestic worker. When the new capital of Lusaka was planned in the early 1930s, a personal servants' compound was laid out, separate from the general African compound, with the belief that "the boy through [his] association with European family life, has reached a higher standard of domestic culture and civic behavior than the more unsophisticated labourer, and is therefore likely to prefer to associate with his fellows." 155

Did servants accept their masters' estimation of their own worth? With the class- and race-conscious white household in front of them, servants certainly learned that manners and dress symbolized white colonists' claim to civilized status. The condescending remarks that whites made about their smartly attired servants were based on the assumption that Africans accepted whites' system of evaluation. But European clothing, and I return to this in Chapter 3, also took on new meanings informed by African cultural practices and helped shape the urban African world of leisure in distinctive ways. Employers and administrators saw only one side of their servants' lives: that part which emerged in the domestic encounter, the part governed by whites' rules. And although these rules circumscribed the behavior of Africans, they did not determine it. The notions that led to

153. NAZ/ZA 1/9/18 no. 25, vol. 1. Department of Native Affairs. Labor: Masters and Servants Ordinances, 1927-1929.

154. Irwin, Far Away, p. 67.

155. Kenneth Bradley, Lusaka 1935 (privately published, 1935; reprinted in In Situ, October 1981, p. 13). Always conscious of differences of status and rank among themselves and between themselves and others, the British also distinguished among Africans. "Special servants," such as those employed in Government House, had their separate residential area at a distance from their place of work but still within walking distance of it. For the convenience of employers, the personal servants' and the government servants' compounds were closer to the white residential areas than was the general African compound located at Lusaka's extreme southwestern corner. 


\section{A Fixture of Colonial Society}

Table 1. Number of African men employed in Northern Rhodesia, by occupation, 1927-1948

\begin{tabular}{|c|c|c|c|c|c|c|c|c|c|c|}
\hline $\begin{array}{c}\text { Occupational } \\
\text { category }\end{array}$ & 1927 & 1928 & 1929 & 1930 & 1931 & 1932 & 1933 & 1934 & 1935 & 1936 \\
\hline Government & 3,708 & 2,979 & 4,777 & 5,101 & 8,146 & 7,580 & 4,582 & 4,111 & 8,023 & 5,423 \\
\hline $\begin{array}{l}\text { Agriculture } \\
\text { Other indus- } \\
\quad \text { trial }\end{array}$ & 16,063 & 15,600 & 10,655 & 10,885 & 10,508 & 6,530 & 5,624 & 8,981 & 10,033 & 9,154 \\
\hline Manufacture & 1,224 & 2,073 & 3,270 & 2,886 & 2,791 & 2,391 & 1,648 & 1,675 & 4,830 & 3,943 \\
\hline Building & 2,502 & 2,236 & 2,277 & 4,420 & 10,133 & 2,464 & 1,640 & 3,769 & 2,005 & 1,789 \\
\hline Mines & 9,493 & 11,036 & 17,608 & 28,004 & 21,888 & 27,851 & 9,920 & 14,245 & 17,298 & 18,326 \\
\hline Railways & 3,223 & 3,500 & 4,399 & 6,808 & 3,204 & 9,666 & 1,582 & 1,592 & 1,500 & 1,671 \\
\hline $\begin{array}{l}\text { Domestic ser- } \\
\text { vice }\end{array}$ & 7,482 & 8,431 & 8,832 & 12,470 & 16,315 & 11,966 & 9,335 & 10,388 & 10,296 & 10,142 \\
\hline Other & & 5,412 & 6,485 & 6,069 & 6,177 & 7,631 & 5,029 & 3,791 & 3,986 & 5,259 \\
\hline Total & 43,695 & 51,267 & 58,303 & 76,743 & 79,162 & 76,079 & 39,360 & 48,552 & 57,971 & 55,707 \\
\hline
\end{tabular}

Source: Northern Rhodesia, Blue Books, 1927-1948 Lusaka, Government Printer.

the formulation of these rules and to the stereotyping of the domestic servant never reckoned with the servants' real characters as individuals or as members of African households with personal affairs, projects, and plans of their own.

The observance of strict interactional rules and the compulsive attention to housekeeping implied that everyone and everything had its place and order reigned over all. But it was a deceptive impression. Not everything was under control, for the terms that structured domestic work did not extend much beyond the locus of work in the colonial household. This inherent limit to the regulative framework impeded the civilizing, educational function that whites ascribed to domestic service in the early years and produced unexpected responses. There was always the lingering suspicion that servants would "revert to type," forgetting everything they had learned, for Africans were considered to be, after all, tribal and by definition different. Then there were servants who took matters in their own hands and, by asserting their independence, sought to transcend the restrictive work regime within domestic service. These responses to domestic service are illustrated by the cases of three menservants recorded in the official colonial registry of correspondence from 1924 to 1951.

The first alternative, "the native who genuinely intends to adopt domestic service as a living and to do his best in his chosen walk of life," 156 was a product of the terms set by the masters. One such servant was Jameson, the head servant at Government House in Lusaka. In 1936 the acting

156. To paraphrase a statement made during the discussion of a registration scheme for servants, taken from the same source as note 142 . 


\begin{tabular}{|c|c|c|c|c|c|c|c|c|c|c|c|}
\hline 1937 & 1938 & 1939 & 1940 & 1941 & 1942 & 1943 & 1944 & 1945 & 1946 & 1947 & 1948 \\
\hline 6,703 & 5,329 & 5,541 & 5,541 & 5,541 & 1,500 & 12,500 & 12,500 & 14,000 & 24,000 & 26,000 & 26,000 \\
\hline 8,595 & 12,826 & 13,500 & 13,500 & 13,500 & 13,500 & 12,000 & 14,000 & 15,000 & 26,000 & 26,000 & 25,000 \\
\hline 5,353 & 5,520 & 6,288 & 6,288 & 4,500 & 4,000 & 4,400 & 4,400 & 5,000 & 9,000 & 10,000 & 12,000 \\
\hline 4,332 & 5,560 & 6,856 & 6,856 & 5,160 & 4,000 & 1,200 & 2,750 & 2,500 & 12,000 & 12,000 & 14,500 \\
\hline 23,689 & 23,754 & 29,524 & 33,396 & 32,400 & 41,330 & 41,987 & 35,000 & 33,000 & 31,000 & 34,000 & 36,500 \\
\hline 1,700 & 5,395 & 5,500 & 2,600 & 1,938 & 2,587 & 2,573 & 2,860 & 2,800 & 3,100 & 3,400 & 3,350 \\
\hline 10,021 & 11,511 & 13,000 & 13,000 & 13,000 & 18,000 & 18,000 & 20,000 & 20,000 & 17,500 & 17,500 & 19,000 \\
\hline 5,747 & & 8,348 & 8,348 & 8,348 & 8,000 & 6,300 & 7,000 & 8,000 & 20,000 & 20,000 & 20,000 \\
\hline 66,140 & 69,895 & 88,557 & 89,529 & 84,387 & 92,917 & 98,960 & 98,510 & 100,300 & 142,600 & 148,900 & 156,350 \\
\hline
\end{tabular}

governor of Northern Rhodesia wrote a letter to Ormsby Gore in the Colonial Office in London requesting a pension for Jameson's retirement. (No arrangements for African pensions existed at this time, so a special request was necessary.) In his letter, he noted that "this native . . . entered the service of the Administration of North Eastern Rhodesia as a tennis boy in 1906, and has given continuous and faithful service as a member of the household staffs of all Administrators and Governors from Sir Robert Codrington down to Sir Hubert Young."157 Jameson may have been the favorite boy Codrington took with him on a visit to Britain in the first decade of this century. In any case, a yearly pension of three pounds was granted to him. Little else is known about him. The official record is silent on how he spent his retirement and used the skills he had acquired in colonial domestic service (as an old retainer, an independent economic man, or a returned migrant, for example). But his conduct as a servant is likely to have been obliging and accepting.

The second response to domestic service, reverting to "type," was to some extent the case with Kakumbi, one of the two servants Gore-Browne had taken to England. ${ }^{158}$ Although Kakumbi was "one of the nicest fellows

157. PRO/CO 705/93. Grant of a Pension to Jameson, Head Native Servant of Government House, Lusaka. Letter from Acting Governor, Northern Rhodesia, to W. G. A. Ormsby Gore, M.P., Colonial Office, December 12, 1936.

158. The possibility of reverting to type puzzled and troubled well-meaning white employers. Kenneth Bradley has aptly captured this tension in his short story "Tomo," in Africa Notwithstanding (London: Lovat Dickson, 1932), pp. 119-182, which revolves around the retirement of an old colonial commissioner's long-time personal servant and his wife to their village. 


\section{A Fixture of Colonial Society}

you could have," domestic serrvice did not successfully civilize him. As Gore-Browne continued in a 1922 letter home, "Not a single scrap he has picked up from all he saw in England \& during the war, though his eyes were wide open \& took a jolly keen interest in everything. . . . yet he still lives in a rubbishy hut full of bugs, still stuffs a few seeds into a patch of ashes on the ground which he doesn't even trouble to hoe, still brews beer, from such grains as he does grow, in the summer and grows hungry in the winter. 159

Bulaya, Gore-Browne's servant who chose to not return to the life of a servant in colonial Northern Rhodesia, exemplifies the third response: asserting independence. His case shows that servants did not always accept their social inferiority to whites or assimilate white norms without question. Some did seek to transcend their situation-although usually on a less grand scale than Bulaya, who became an actor in England and married a white woman. They must have done so in ways defined by their own experience and what they saw as alternatives. These three responses to domestic service are likely to have overlapped at times during an individual servant's life.

Peter Fraenkel, broadcasting officer in Lusaka in the 1950s, in his book Wayaleshi, offers us a rare case from the war and postwar period which illustrates this process. His account details many of the aspects I have been sketching and is especially illuminating because it presents the servant as a person with an ethnic background, family ties, a social life, and, last but not least, a purpose and conscience of his own. ${ }^{160}$ Fraenkel writes of the life and work of Amon, a Lenje man, born Amon Chapusha, who with two years' primary schooling had learned to read but barely to write. At ten he began to work for a poor Afrikaans-speaking farmer, some thirty miles from his village, as a nurse-boy for the baby. He left that household after being severely beaten. Next he was taken on by a nearby British farmer, a retired civil servant known for his contempt of the poor white Afrikaaners. Amon worked as a kitchen boy, peeling potatoes and chopping firewood. $\mathrm{He}$ stayed for several years, advancing to houseboy, cleaning rooms and serving at table. Then he decided to seek his fortune in town: "Money was very little on these farms. I got 15 shillings and food per month. Also, I was bored." It was around the late 1930s that he came to Lusaka and was employed by Fraenkel's parents, Jews from Breslau, first as a houseboy, then as cook.

Amon was a variable worker, writes Fraenkel. If there was anything new and interesting to do, such as preparing a dish he had never tried or

159. Rotberg, Black Heart, p. 121.

160. Peter Fraenkel, Wayaleshi (London: Weidenfeld and Nicolson, 1959). All quotations are from pp. 124-130. 


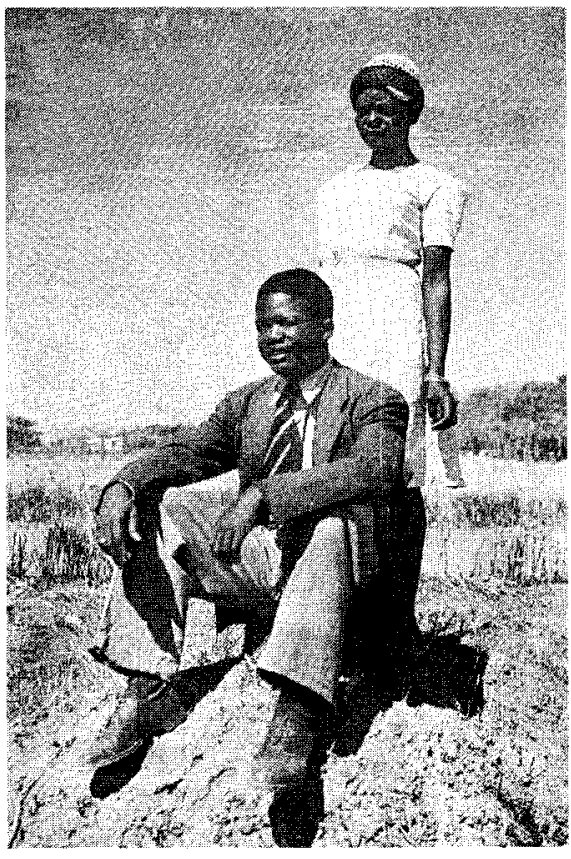

Amon Chapusha and his wife. Lusaka, 1950s. From the collection of Peter Fraenkel. Reproduced with permission.

repairing the plumbing, he was enthusiastic and enterprising. Routine work he found boring and did indifferently.

Amon married, but his wife soon gave him grounds for suspicion. He tried to divorce her, but there was difficulty because she was the daughter of a minor chief. ("I suspect," comments Fraenkel, "that his own marital record was not as clean as he claimed.") Amon's life made him listless. He did not know what to do with his spare time as there were few channels for his talents. He had no ambition to excel at tribal dancing or beer drinking because they were "uncivilized." He once bought an English primer and tried to learn English. During Fraenkel's vacations from boarding school he helped the African, but when school was on Amon lost interest. Yet he had a restless, inquiring mind, and he started to ask awkward questions.

"If we all were created in God's image, why are some of us black and white? What colour is God? If God really loved the world why did he create some to enjoy life and some to suffer?" One day he surprised Fraenkel: "This story about Adam and Eve and the snake and the apple, I think the Bible is speaking in riddles like our own people. What it really means is that Adam had discovered how sweet women were. What do you think?" These questions were the fruit of lengthy theological speculation and controversy he heard in his compound from lay preachers of the Watchtower Bible and Tract Society, or Jehovah's Witnesses, on their house-to-house 


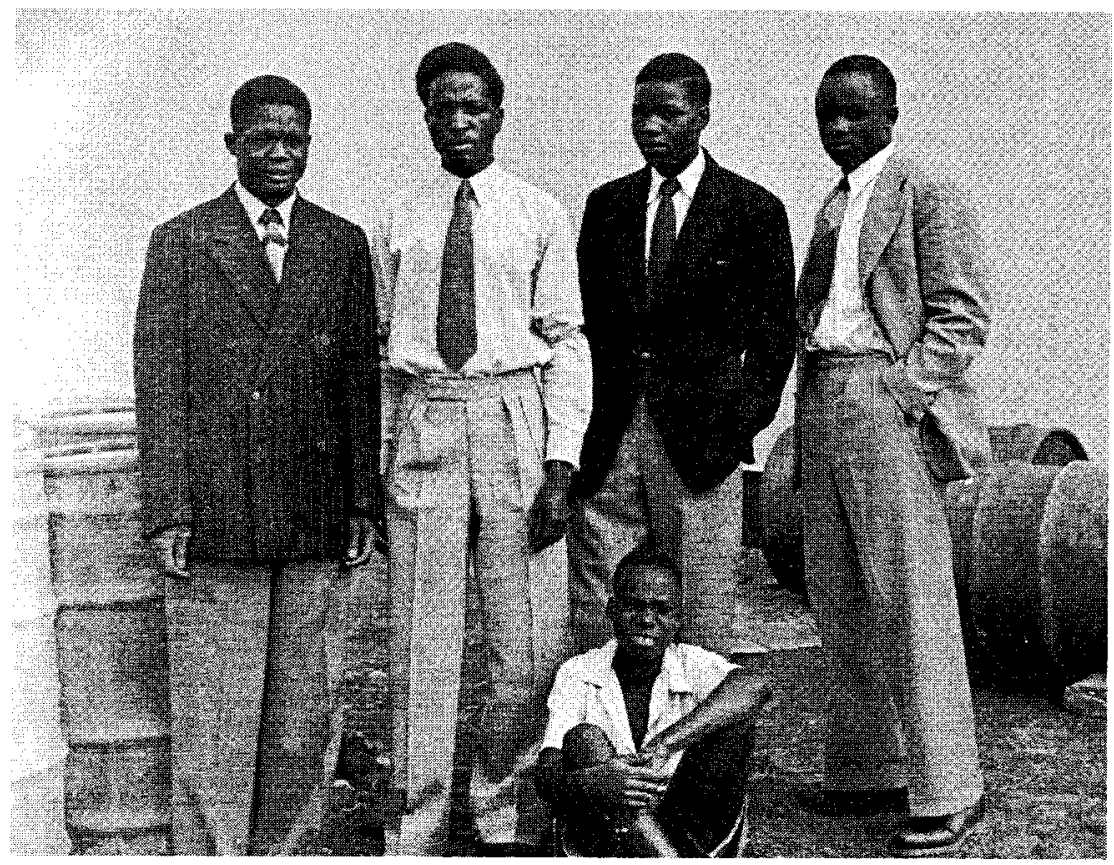

Amon Chapusha (extreme left) and co-workers at Express Dry Cleaners, Lusaka, 1950s. From the collection of Peter Fraenkel. Reproduced with permission.

visits. The society had grown to become the biggest single denomination in Northern Rhodesia during the 1930s and 1940s. In Lusaka in the 1930s, 75 percent of the African population were among its adherents. ${ }^{161}$ It alone of all the Christian denomination was not tainted by identification with the white establishment, for while "the society" called for salvation, it was also political. In the 1940s its teachings increasingly criticized the economic and political order on which white privilege was based. ${ }^{162}$ Its message appealed to Amon. He brought a Nyanja Bible and began to read in his spare time, in the kitchen, under the bananas in the garden, and in his little round mudhouse in the compound. There was no priestly hierarchy to hinder the progress of a humble, uneducated man. Soon he began to accompany lay preachers on their rounds and he joined the choir. His former gossiping

161. Norman Rothman, "African Urban Development in the Colonial Period: A Study of Lusaka, 1905-1964" (Ph.D. diss.: Northwestern University, 1972), p. 340.

162. Rothman, pp. 340-344. For a historical study of the Watchtower movement, see Sholto Cross, "The Watchtower Movement in South Central Africa, 1908-1954" (Ph.D. diss.: Oxford University, 1973). 
was transformed into preaching with an urgent purpose. His ability came to be recognized and he was happier than Fraenkel had ever known him.

Amon found that the irregular hours of domestic service interfered with his preaching, and he had ambitions. He asked to be transfered to the Fraenkel dry-cleaning business. There he immediately made himself helpful by repairing the electrical equipment and delivery bicycles. He was soon a sort of foreman.

After Amon had worked for the family for twelve years, Fraenkel senior disposed of the business. Amon turned down another servant job to start a dry-cleaning business of his own. Working from his house in the compound, he developed a flourishing trade among Africans and some whites. He expanded and employed several younger relatives. His enterprise eventually folded, when a nephew employee ran off with the clothes taken in for cleaning and Amon had to pay for them. He did not have enough money and disappeared to his village.

The unhappy ending does not diminish the importance of Amon's story. His experience is probably not unique among the many unrecorded stories of African servants who, conscious to their disadvantageous position in colonial society, found alternative means (many through the Watchtower) to transcend their situation.

During the period covered in this chapter, an educated African man's employment horizon was limited to a job as interpreter in the courts, a lowly clerical post, or teaching. Beyond that, there was manual labor, including domestic service, and African menservants remained fixtures of household employment throughout the colonial period. The construct of the good and faithful manservant, at times inefficient and lazy because of mental incapacity but obligingly taking orders with a simple mind and no questions asked, had changed by then and servants were increasingly considered "subversive." Before the how and why can be discussed in Chapter 3 , African women must be brought into the story. The written record has given them little room other than as tangents to men, as mothers and daughters, sisters and wives, lovers and prostitutes. Despite their subsidiary role, however, women were by their absence in fact central to the shaping of colonial domestic service as a male institution. 